"Niosomes based on synthetic cationic lipids for gene delivery: the influence of polar head-groups on the transfection efficiency in HEK-293, ARPE-19 and MSC-D1 cells" Ojeda, E., Puras, G., Agirre, M., Zarate, J., Grijalvo, S., Pons, R., Eritja, R., MartínezNavarrete, G., Soto-Sánchez, C., Fernández E., Pedraz, J.L. Org. Biomol. Chem., 13, 1068-1081 (2015). Doi: 10.1039/C4OB02087A

\title{
Niosomes based on synthetic cationic lipids for gene delivery: The influence of polar head-groups on the transfection efficiency in HEK-293, ARPE-19 and MSC-D1 cells.
}

Ojeda, E. ${ }^{1,2 a}$; Puras, G. ${ }^{1,2 a}$; Agirre, M. ${ }^{1,2}$; Zárate, J. ${ }^{1,2}$; Grijalvo, S. ${ }^{2,3}$; Pons, R. ${ }^{2,3}$; Eritja, R. ${ }^{2,3}$; Martinez-Navarrete, G. R. ${ }^{2,4}$; Soto-Sanchez, C. ${ }^{2,4}$; Fernández, E. ${ }^{2,4}$; Pedraz, J.L. ${ }^{1,2, *}$

${ }^{1}$ NanoBioCel Group, University of Basque Country, Vitoria, Spain.

${ }^{2}$ Networking Research Centre of Bioengineering, Biomaterials and Nanomedicine (CIBER-BBN)

${ }^{3}$ Institute of Advanced Chemistry of Catalonia, IQAC-CSIC, Barcelona, Spain.

${ }^{4}$ Neuroprothesis and Neuroengineering Research Group, Miguel Hernández University, Spain

${ }^{\mathrm{a}}$ These two authors contributed equally to this work.

* Corresponding author: Jose Luis Pedraz, Ph.D. Laboratory of Pharmacy and Pharmaceutical Technology, Faculty of Pharmacy, University of the Basque Country, 01006, Vitoria-Gasteiz, Spain. E-mail address: joseluis.pedraz@ehu.es. Phone: + (34)-945013091. Fax number: + (34)-945013040.

\begin{abstract}
We designed niosomes based on three lipids that differed only on the polar-head group to analyze the influence on the transfection efficiency. These lipids were characterized in terms of small-angle X-ray scattering before being incorporated into the niosomes which were characterized in terms of pka, size, zeta potential, morphology and physical stability. Nioplexes were obtained upon the addition of plasmid. Different ratios $(\mathrm{w} / \mathrm{w})$ were selected to analyze the influence of this parameter on size, charge and on the ability to condense, release and protect the DNA. In vitro transfection experiments were performed in HEK-293, ARPE-19 and MSC-D1 cells. Our results show that the chemical composition of the cationic head-group clearly affects to the physicochemical parameters of the niosomes and specially, to the transfection efficiency. Only niosomes based on cationic lipids with a dimethyl amino head group (Lipid 3) showed transfection capacity when compared with their counterparts amino (Lipid 1) and tripetide head-groups (Lipid 2). Regarding cell viability, we clearly observed that nioplexes based on the cationic lipid 3 had a more deleterious effect than their counterparts, especially in ARPE-19 cells at 20/1 and 30/1 ratios. Similar studies could be extended to other series of cationic lipids in order to progress in the research of safe and efficient non-viral vectors for gene delivery purposes.
\end{abstract}

Keywords: cationic lipids; gene therapy; niosomes; non-viral vectors; transfection; 


\section{INTRODUCTION}

Gene therapy has become one of the main areas of interest for scientists, because it focuses on the possibility of delivering a normal functioning gene into the cell in order to have a therapeutic effect 1 . However, efficient delivery and expression of genes into cells is not as easy as it seems. The entry of the DNA into cells and the protection of the genetic material against enzymatic digestion before reaching the nucleus, are two important factors that may clearly hampers this process. Other factors to be considered for the development of effective gene carriers include the intracellular trafficking and the subsequent entry into the nucleus in order to express the desirable molecule. ${ }^{2}$ Basically, there are two main gene carrier systems classified as viral and non-viral vectors. Viral vectors rely on the use of viruses as carriers due to their natural ability to insert genetic material into the cells. However, some serious concerns such as immunogenicity, oncogenicity and the high cost of production jeopardize their use in human beings. ${ }^{3}$ On the other hand, non-viral vectors based on cationic lipids or polymers offer a safer way to deliver genetic material, as they exhibit lower risk of antigen-specific immune and inflammatory response. Moreover they are cheaper and easier to elaborate, and the size of DNA inserted is theoretically unlimited. ${ }^{4}$ However, non-viral vectors are less effective than viral vectors as gene cariers Therefore, research on the design of safe and effective novel non-viral vectors merits special attention for the research community.

Niosomes are non-ionic surfactant vesicles with a bilayer structure that have been effectively used to vectorize many kinds of drugs. ${ }^{5,6}$ Unfortunately, these outcomes have not been the same for gene therapy purposes where their use is still limited; however some promising results have been recently reported in the literature for retinal gene delivery purposes. ${ }^{7}$ Therefore, research on niosomes as non-viral vectors represents a challenge topic to be further developed. Compared with liposomes, niosomes are recognized for their low cost and superior chemical and storage stabilities. The structure and physical properties of niosomes are similar to liposomes, with the only difference that niosomes are prepared using non-ionic surfactants instead of phospholipids. Basically, there are three main components in a niosome formulation: a) Non-ionic surfactants such as polysorbate 80 and span that form stable emulsions, ${ }^{8}$ b) helper lipids such as cholesterol or squalene that enhance the physicochemical properties of the lipid emulsion $^{9,10}$ and c) cationic lipids, which structure and physical properties clearly influence on the transfection efficiency and toxicity. ${ }^{11}$

Most of the cationic lipids employed for gene delivery purposes contain four functional domains: a hydrophilic head-group, a hydrophobic domain, a linker, and a backbone domain. The hydrophobic group is usually derived from aliphatic hydrocarbon chains. Classically, the hydrophobic domain often contains two linear aliphatic chains, because it has been reported that cationic lipids containing one or three carbon chains tend to be more toxic and show poor transfection efficiencies. ${ }^{12}$ The linker group influences on the flexibility, stability, and biodegradability of the cationic lipid, while its length determines the level of hydration. ${ }^{13}$ The backbone separates the polar-head group from the hydrophobic group, being serinol and glycerol groups the more popular units. ${ }^{14}$

Finally, the hydrophilic head-group is responsible of the interaction with DNA and its condensation to form complexes due to electrostatic interactions. ${ }^{15}$.

In the present study, we designed niosome vectors based on three synthetic amino lipids containing polysorbate 80 as non-ionic surfactant and squalene as helper lipid. Our three 
cationic lipids were synthesized containing the same serinol backbone with two identical fully hydrocarbonated alkyl chains, varying only the cationic head structure with an amino (Lipid 1), a tripeptide (Lipid 2) and a dimethyl amino group (Lipid 3) (Fig. 1) in order to study the influence of the polar-head group on the transfection efficiency and cell viability. The amino polar-head group (Lipid 1) was selected based on the excellent transfection results obtained when it was incorporated to a glycerol derivative cationic lipid. $^{7}$ The dimethyl amino group (Lipid 3) is considered as one of the most suitable pendant groups for cationic lipids to be used in transfection experiments, for this reason was selected as a polar-head group. Finally, the tripeptide group (Lipid 2) was selected as polar head group as this compound has a lower pKa than dimethyl amino and amino groups and it may form potential intermolecular $\mathrm{H}$-bonds. These novel cationic lipids were analyzed by small-angle X-ray scattering (SAXS). Niosomes prepared by oil-inwater emulsion (o/w) and film-hydration technique were characterized in terms of pka, size, zeta potential, morphology and physical stability. Upon the addition of the pCMSEGFP reported plasmid, we obtained nioplexes at different cationic lipid/DNA ratios (w/w). The influence of cationic lipid/DNA ratios on particle size, zeta potential and on the ability to condense, release and protect the DNA from enzymatic digestion was analyzed. In vitro experiments were performed with the most promising formulations to evaluate the transfection efficiency and viability in HEK-293, ARPE-19 and MSC-D1 cells. Delivery carriers prepared by biomolecular assembly and conjugation have been extensively reported in the literature. ${ }^{16-18}$

\section{RESULTS AND DISCUSSION}

\subsection{Synthesis of ionizable amino lipids}

The synthesis of the three proposed ionizable amino lipids (1, 2 and $\mathbf{3})$ is displayed in Fig. 2. The synthesis started with the double alkylation of the $N$-protected diol $\mathbf{4}$ in the presence of tetradecyl bromide and sodium hydroxide (50\%) by using the transfer-phase catalyst reaction. This reaction afforded the alkylated compound $\mathbf{5}$ with moderate yields (54\%). Then, $N$-Boc deprotection in acid conditions $\left(\mathrm{CH}_{2} \mathrm{Cl}_{2} /\right.$ TFA $\left.10 \%\right)$ and subsequent treatment with Amberlyte IRA-900 yielded in quantitative form the expected di-alkylated amine 1 (Lipid 1) in its free form.

Further amine functionalization with an activated Boc-Gly-Gly-Gly-OH afforded the protected $\mathrm{N}$-Boc-dialkylated tripeptide $\mathbf{6}$ with good yields. Boc-deprotection using the same acid conditions described before achieved the expected Lipid $\mathbf{2}$ in quantitive yield. Finally, a $N, N$-dimethylethylenediamine residue was successfully introduced into the Lipid 1 by activating 1 with $p$-nitrophenyl chloroformate. This reaction generated the expected Lipid 3 with good yields. (For more details see the supporting information section 1).

\subsection{Small Angle X-ray Scattering (SAXS) analysis of cationic lipids}

In Fig. 3-A, we show the SAXS curves at $25^{\circ} \mathrm{C}$ corresponding to the three amino lipids. No significant differences were observed at $37^{\circ} \mathrm{C}$ (data not shown). For the lipid 1 three equidistant peaks can be clearly observed while for lipid 2 up to 4 equidistant peaks are apparent. In contrast, for lipid $\mathbf{3}$ the three observed peaks are not equidistant and the 
peaks appear at positions $q_{1}: 2 q_{1}: 4 q_{1}$. In this case the peak that should appear at $3 q_{1}$ is absent due to the bilayer form factor. The presence of equidistant peaks is the sign of a lamellar structuring of the system; therefore, we have fitted a modified Caille Gausian model to the SAXS curves. In this model, the bilayer structure is calculated with two Gausian corresponding to the polar heads at both sides of the bilayer and one Gausian at the center of the bilayer corresponding to the low density methyl terminal groups of the hydrophobic chains. In addition, the contribution of the methylene groups of the chains is provided by a symmetric error function. ${ }^{19}$ The layered structure is calculated using the modified Caillé structure factor as found in the literature. ${ }^{20,21}$ The electronic profiles are shown in Fig. 3-B, and the main parameters of the fit in Table 1 (this material is available in the supporting Information section 2). Lipid $\mathbf{1}$ is the one that shows a most clear methylene dip at the center of the bilayer, this is usually associated to strong order in the hydrophobic domain (the so-called gel phase found for phospholipids). The lipid $\mathbf{3}$ also shows a distinct low electronic density region at the center of the bilayer, albeit less defined than lipid 1, while the dip has completely disappeared for lipid $\mathbf{2}$. This corresponds to a more fluid hydrophobic domain for lipid 2.

The other remarkable difference between the lipids is the amount of water hydrating the polar heads. While lipid $\mathbf{1}$ is hydrated by at most 1 water molecule and there is virtually no water in the liquid crystal, the liquid crystals formed by lipid $\mathbf{2}$ and lipid $\mathbf{3}$ contain similar amount of water, around 11 water molecules per lipid. There is, however, a striking difference between water location in the liquid crystal formed by lipid $\mathbf{2}$ and lipid 3. As it can be observed in Fig. 3-B, the high electronic density of lipid $\mathbf{2}$ is distributed, reaching the limit of the bilayer while that of lipid $\mathbf{3}$ remains quite tightly bound to the hydrophobic domain of the bilayer. The meaning of this is that the polar region of lipid $\mathbf{3}$ contains almost no water and most of the water between the bilayers is free.

\subsection{Determination of niosomal pKa by fluorescence}

Liposomal $\mathrm{pK}$ have been used to predict the efficacy of formulations containing ionizable amino lipids to encapsulate and mediate delivery of different cargoes into cells. $^{22}$ This parameter, in particular, has been used both in rational design of lipids ${ }^{23}$ and structure-activity relationship (SAR) studies in order to analyze combinatorial libraries of lipids by varying the amino cationic head group, linker or hydrophobic chains and thereby designing more efficient vehicles for in vivo applications.

There are two different approaches that have been reported in order to measure amino lipid pKa values: 1) potentiometric titration of amino lipids prepared in niosomes and 2) the effect of 2-( $p$-toluidino)-6-naphtalene sulfonic acid (TNS) fluorescence at different $\mathrm{pH}^{24}$

In our case, the use of the second approach allowed us to determine the acid dissociation constant of our niosome formulations containing the ionizable amino lipids $\mathbf{1}, \mathbf{2}$ and $\mathbf{3}$, respectively by in situ TNS fluorescence titration from $\mathrm{pH} 2.5$ to 11.0 (Fig. 4-A, 4-B and 4-C). As displayed in Fig. 4, the amino lipids $(\mathbf{1}-\mathbf{3})$ containing the same hydrophobic alkyl region and serinol backbone but modifying only the cationic head group was sufficient to affect the $\mathrm{pK}$ a value for the corresponding niosomes. Therefore, the halfmaximal fluorescence intensity afforded niosomal $\mathrm{pK}$ a values that ranged from 6.63 to 7.00 (lipid 1, $\mathrm{pK}_{\mathrm{a}}=7.00$; lipid 2, $\mathrm{pK}_{\mathrm{a}}=6.63$ and lipid 3, $\mathrm{pK}_{\mathrm{a}}=6.72$, respectively). As displayed in Fig. 1, lipids $\mathbf{1}$ and $\mathbf{2}$ have a primary amino group. Lipid $\mathbf{1}$ has a higher pKa 
than lipid 2. This is consistent with the presence of the electron-withdrawing amide groups in lipid $\mathbf{2}$ that lower the pKa. Moreover, lipid $\mathbf{3}$ is a tertiary amine with electronwithdrawing groups and for this reason the $\mathrm{pKa}$ is higher than the lipid $\mathbf{2}$. It has been suggested that the optimal pKa of cationic lipid for transfection should be $<7.0$ as in this way a large number of amino groups would be neutral at physiological $\mathrm{pH} 7.4 .^{23}$ If this suggestion is correct, then the pKa of the amino lipids described in this work could fall the optimal range for transfection.

\subsection{Particle size, zeta potential and morphology evaluation of niosomes}

It has been widely reported that the uptake and transfection efficiency of non-viral vectors strongly depends on the method of elaboration, which clearly impact on some physicochemical parameters including size, zeta potential and morphology. ${ }^{25}$ Therefore, we prepared niosomes based on the three synthesized amino lipids by o/w emulsion and film-hydration techniques. Resulted niosomes were characterized in terms of size, zeta potential and morphology (Fig. 5). We observed that zeta potential values were similar between both techniques for the three niosome formulations (Fig. 5-A, lines). Interestingly, the highest zeta potential values were obtained when niosomes were based on lipid $\mathbf{3}(\approx+30 \mathrm{mV})$, independently of the elaboration technique. Regarding particle size values (Fig. 5-A, bars), we did not find differences between the niosomes when these were elaborated by the film hydration technique (values around $200 \mathrm{~nm}$ ). However, smaller particle sizes were obtained when niosomes based on the lipid $\mathbf{2}$ were formulated by the film-hydration technique $(\approx 150 \mathrm{~nm}$ ). In addition to the size and charge, the homogeneity of the suspension containing nanoparticles should be also considerate, since this parameter affects to the formation of the nioplexes (after the addition of plasmid) and the subsequent cell internalization processes. ${ }^{26} \mathrm{We}$ determined the polydispersity index (PDI) as a measure of homogeneity (Fig. 5-B). Our data clearly revealed that the lowest $\mathrm{PDI}$ values were obtained when niosomes were prepared by the $\mathrm{O} / \mathrm{W}$ emulsion technique, and these values were similar, independently of the lipid employed to formulate the niosomes. However, when niosomes were elaborated by the film-hydration technique, PDI values were extremely high, especially for niosomes elaborated with the lipids $\mathbf{1}$ and 3 (0.9 and 1.0 values respectively), which indicates that these suspensions had a very broad size distribution. Therefore, the cumulative analysis to determine particle size does not apply to scenario. Consequently, we discarded for the following experiments the niosomes that were prepared using film-hydration technique.

To get a direct evidence of the niosomes formation, we examined niosomes elaborated by the $\mathrm{O} / \mathrm{W}$ emulsion technique with the three cationic lipids under a Cryo- TEM microscope (Fig. 5-C). In our experimental conditions, all niosomes, especially those elaborated with the lipid 3 (Fig. 5- $\mathrm{C}_{2}$ ) adopted a spherical and homogeneous morphology, which is the most favorable structure from an energetic point of view.

In all niosome formulations, sizes reported by Cryo-TEM (around $100 \mathrm{~nm}$ or less) were slightly smaller than the sizes reported by dynamic light scattering (around $200 \mathrm{~nm}$, Fig. 5-A, bars). Such differences in the sizes of the niosomes could be explained by the sample manipulation required to perform Cryo-TEM analysis.

\subsection{Physical stability of niosomes}


Instability of niosomes can be seen as a merging of one or more particles and thus formation of aggregates that result in an increase on the particle size throughout the testing period. Therefore, the bigger is the size, the more unstable the niosomal system is. Normally, the electrostatic repulsions among the vesicles are due to the surface charge. As a rule of thumb, high surface charges of the vesicles (above $20 \mathrm{mV}$, absolute value) should provide enough electrostatic repulsion to prevent the formation of aggregates. ${ }^{10}$ We measured the physical stability of niosomes based on the three cationic lipids by monitoring the particle size and the zeta potential after storage for 100 days at $4^{\circ} \mathrm{C}$ and $25^{\circ} \mathrm{C}$ (Fig. 6). Our data shows that stability of niosomes strongly depended on the storage temperature and on the cationic lipid used to elaborate the niosomes. Clear decreases on the zeta potential value along the time was observed when niosomes based on lipid 1 and especially on lipid 2 , was stored at $25^{\circ} \mathrm{C}$. In the case of niosomes based on the lipid 2 , the decrease on zeta potential led to a clear increase in the particle size, resulting in unstable niosomes due to the reduction of the electrostatic repulsions. ${ }^{27}$ However, zeta potential and size of niosomes based on the lipid $\mathbf{3}$ did no vary too much along the time when stored at $25^{\circ} \mathrm{C}$, which clearly indicates that the polar head-group of the cationic lipid strongly affects to the niosome stabilities. When samples were stored in the refrigerator at $4^{\circ} \mathrm{C}$, we did not observe a clear decrease on the zeta potential value along the time, with the exception of niosomes based on the lipid 2 which clearly was unstable after 100 days of storage at $4^{\circ} \mathrm{C}$. Again, a decrease in the zeta potential value led to a clear increase in the particle size. Temperature can lead to changes in the crystalline structure of lipids due to changes in zeta potential, as previously reported. 28 In conclusion, niosomes based on lipids 1, 2 and $\mathbf{3}$ were more stable when were stored at $4^{\circ} \mathrm{C}$, specially, niosomes based on the lipid 3, which size and zeta potential values did not strongly vary along the 100 days duration of the study.

\subsection{Characterization of nioplexes in terms of size and zeta potential}

Adding DNA to the niosomes at different cationic lipid/DNA ratios (w/w) formed nioplexes that were characterized by charge and size parameters (Fig. 7). A clearer decrease in zeta potential value (Fig. 7, lines) was observed in the three noisome formulations when DNA was added at a cationic lipid/DNA mass ratio of $1 / 1$. For niosomes based on the lipid 1, the charges oscillated from 18 to $-35 \mathrm{mV}$, for niosomes based on the lipid 2 , these charges oscillated from 19 to $-48 \mathrm{mV}$ and for niosomes based on the lipid 3, charges oscillated from 31 to $-41 \mathrm{mV}$. Interestingly, in all nioplexes formulations, zeta potential values increased proportionally to the cationic lipid/DNA mass ratio, reaching the maximum values at the highest cationic lipid /DNA ratio 30/1 $(+8 \mathrm{mV},+10 \mathrm{mV}$ and $+22 \mathrm{mV}$ for nioplexes based on lipid 1, 2 and $\mathbf{3}$ respectively). This increase in the charge was more evident for the nioplexes prepared with the lipid $\mathbf{3}$. The clear relationship between the cationic lipid/DNA mass ratio and the superficial charge demonstrates that at an appropriate mass ratio, cationic niosomes were able to bind and neutralize the negative charges of the DNA, 29 resulting in positively charged nioplexes that can easily interact with the negatively charged cell surfaces, inducing early steps of the endocytosis process, which finally increases transfection efficiency. ${ }^{30}$

Regarding the size of nioplexes (Fig. 7, bars), results in general showed that the increase of the cationic lipid /DNA ratios from 1:1 to 30:1 did not significantly affect to the final size, with some exceptions such as niosomes based on cationic lipid $\mathbf{1}$ at 25:1 and 30:1 
ratios (Fig 7-A). These slight increases in the final size could be due to the achievement of a final zeta potential value near to 0 , which results in less compacted and bigger nioplexes. In general, most of the nioplexes showed a final size value under $200 \mathrm{~nm}$, which has been report to be adequate for intracellular uptake and therefore transfection. ${ }^{31}$ It is generally accepted that the mass ratio influences on the particle size of nioplexes. ${ }^{29}$ However in our experimental conditions, we did not find relevant differences, probably because the final particle size of the resulted nioplexes may depend on a delicate balance between the ability of the cationic niosome to precondense with the DNA which reduces the particle size, and the greater space demanded by the noisome itself, which increases the particle size. ${ }^{7}$

\subsection{Agarose gel electrophoresis studies of nioplexes}

To further analyze the electrostatic interactions between the niosomes based on the three cationic lipids and the DNA, we performed an agarose gel electrophoresis assay, since an optimum balance between DNA condensation and release is mandatory to enhance transfection efficiency. ${ }^{32}$ Additionally, DNA can be easily degraded by enzymes in the cytosol before reaching the nucleus. ${ }^{33}$ Therefore, we studied the DNA protection capacity of niosomes based on the three cationic lipids against DNase enzymatic digestion, in order to design efficient non-viral carriers for gene delivery purposes. Based on the data obtained in Fig. 7, we selected 6/1, 10/1, 20/1 and 30/1 cationic lipid/DNA mass ratios to perform the agarose gel electrophoresis studies, since at cationic lipid/DNA mass ratios below 6/1, the zeta potential values of resulted nioplexes were negatives when nioplexes were formulated with lipid 1 and lipid 2. Data of agarose gel electrophoresis assays are shown in Fig 8.

Nioplexes based on cationic lipid 1 (Fig. 8-A) failed to condense and therefore, to protect the DNA against enzymatic digestion. Clear SC bands on lanes 4, 7, 10 and 13, suggest that unbound DNA was able to migrate through the gel at 6/1, 10/1, 20/1 and 30/1 cationic lipid/DNA mass ratios, respectively. As expected, DNA was easily released from the niosomes based on cationic lipid 1 upon the addition of SDS at all ratios studied, because clear SC and OC bands (in some cases comparable to control lane 2, free DNA) were observed on lanes 5, 8, 11 and 14. Interestingly, faint SC band observed at all mass ratios suggested that the DNA was partially digested upon exposition to DNases when niosomes were formulated with the lipid $\mathbf{1}$, which anticipates poor performance in next in vitro transfection experiments.

Regarding nioplexes based on the cationic lipid 3 (Fig. 8-B), we clearly observed that the condensation capacity was superior to that observed when niosomes were formulated with lipid 1 (Fig. 8-A), since most of the DNA remained retained in the well and not clear SC bands were observed on lanes 4, 7, 10 and 13. Additionally, protection capacity increased proportionally to the cationic lipid/DNA mass ratios. Therefore, at low mass rations $(6 / 1$, lane 4$)$ niosomes were no so efficient to condense DNA. When SDS was added, niosomes were able to release the DNA at all cationic lipid mass ratios analyzed (lanes 5, 8, 11 and 14), which reveals that electrostatic interactions between niosomes based on the lipid 3 and DNA are strong enough to condense DNA, but at the same time, DNA can be easily released from the niosomes upon the addition of SDS, which is an optimal condition for gene delivery purposes. ${ }^{34}$ Protection assays against enzymatic digestion revealed that niosomes based on cationic lipid 3 not only condensed and 
released the DNA, but also efficiently protected the DNA against enzymatic digestion at all ratios, since clear SC bands, the most bioactive form, ${ }^{35}$ were observed on lanes 6,9 , 12 and 15.

Nioplexes based on the cationic lipid 2 (Fig. 8-C) clearly failed to protect the DNA, as observed by the absence of SC or even OC bands on lanes 6, 9, 12 and 15, despite the fact that niosomes condensed and released properly the DNA after the addition of SDS. Protection capacity of DNA against enzymatic digestion is a mandatory issue that merits special attention for the design of efficient gene delivery vectors. ${ }^{36} \mathrm{We}$ hypothesize that electrostatic interactions between the cationic lipid $\mathbf{2}$ and DNA are efficient to condense the DNA, but are not strong enough to protect the DNA.

The absence of DNA bands on lane 3 (Fig 8-A, B and C) confirms that the enzyme worked properly in all experiments carried out.

\subsection{In vitro transfection experiments in HEK-293, ARPE-19, and MSC-D1 cells}

One of the main goals of non-viral gene delivery systems is to emulate transfection efficiencies obtained with viral vectors. Therefore, the synthesis and development of new safe and efficient non-viral vector carriers represents an attractive challenge for the scientific community that need to be overcome in order to beat gene therapy based on viral vectors.

A single vector is unlikely to be optimal for all applications, since lipofection efficiency is a cell dependent process. ${ }^{37,38}$ Therefore, transfection efficiency needs to be studied and evaluated in different cell lines, as we have presented in the current study.

Human embryonic kidney cells (HEK-293) have been extensively used as a well-known and easy to transfect model ${ }^{39}$ Human retinal pigment epithelial cells (ARPE-19) are more difficult to transfect cells. ${ }^{36}$ These cells are essentials for neural retina homeostasis and play a major role in genetic ocular diseases associated with senescence and dystrophies of the photoreceptors. ${ }^{40}$ Finally, mesenchymal stem cells (MSC-D1) have shown flattering characteristics for different medicine applications due to their capacity of differentiation (osteocytes, chondrocytes or adipocytes) and their ability to produce immunosuppression upon transplantation to name just a few. Therefore, MSC-D1 cells represent an attractive model for the development of safe non-viral vectors carriers despite the lack of articles reported on the literature. ${ }^{41}$

Transfection results are shown on Fig. 9-A. As can be observed, only those nioplexes based on cationic lipid 3 showed relevant percentages of transfection. In all cases, the highest percentages were obtained in HEK-293, reaching 33\% of transfection at the cationic lipid/DNA ratio 10/1. This value is clearly superior to the maximum transfection values obtained in both ARPE-19 (8\% at 10/1 ratio) and MSC-D1 cells (1\% at 20/1 ratio). Such differences found on transfection values among the cells could be explained by the different cell line dependent barriers that nucleic acids need to face before reaching the cellular machinery for protein synthesis, such as cellular uptake, structural changes caused by interactions with cellular lipids and posterior intracellular trafficking processes. $2,42-44$

The lack of transfection observed when cationic lipids $\mathbf{1}$ and $\mathbf{2}$ were used to obtain nioplexes in the three cell lines suggests that the polar head-group of the cationic lipid plays a pivotal role on transfection efficiency. Therefore, minor structural changes performed in the cationic lipid head-groups, such as the inclusion of one additional 
methylene moiety, are able to change dramatically gene transfer efficiencies, as previously reported by Singh et $a l^{45}$ Moreover, these differences obtained in transfection efficiencies with our three formulations might be hypothesized to several causes such as particle hydrophobicity, electrostatic interactions, lipid structures, or formation of aggregates between nioplexes. ${ }^{46,47}$

More specifically, the presence of the dimethylaminoethyl moiety as hydrophilic cationic head in the lipid $\mathbf{3}$ was able to impart efficiently cellular uptake of pDNA.

Reported transfection experiments performed with other cell lines in vitro and/or in vivo using the same modification and other dimethylamino derivatives have shown the importance to maintain this cationic head into the lipid structure, probably due to the easiness of these amino lipids to ionize and the tendency to interact with biomembranes. ${ }^{48,}{ }^{49}$ Thus, niosome $\mathrm{pK}$ a value for niosomes based on cationic lipid $\mathbf{3}$ ( $\mathrm{pK}_{\mathrm{a}}=6.72$, Fig. $4 \mathrm{C}$ ) confirmed the correlation between activity and ionization behavior. Besides the dissociation effect observed for the lipid 3, the interaction between the cationic lipid and the DNA can influence on the transfection efficiency. In fact, this structuring promotion is not only due to the lipid itself, but also to the compounds that are used to prepare the niosomes, such as the squalene which can promote the inverted hexagonal phase by facilitating the lamellar to inverted hexagonal phase transition of phospholipids causing the endosome swelling and promote membrane fusion. ${ }^{50}$ Surprisingly, this superior transfection property described before for the lipid $\mathbf{3}$ was not observed for niosomes containing the lipids $\mathbf{1}$ and $\mathbf{2}$ which did not promote delivery of DNA in vitro even having similar dissociation constants ( $\mathrm{pK}=7.00$ and 6.63 for lipid 1 and 2, respectively; Fig. 4A, B). This lack of activity could be attributed to both molecular shape of the cationic lipid and the formation of closed-pack units based on electrostatic interactions and van der Waals' attractions (Fig. 3-B). ${ }^{51}$ Consequently, these nioplexes might be unable to adopt the hexagonal morphology because of niosome packing that could become more stabilized and thereby inactivating the delivery process. ${ }^{52}$ As a consequence, these results also evidenced that $\mathrm{pK}$ a constant is a necessary but not sufficient condition for having a good DNA delivery into the cell. ${ }^{48}$ When examining other relevant physicochemical properties for gene deliver purposes such as size, zeta potential or morphology (Fig. 5), we found that niosomes based on the cationic lipid $\mathbf{3}$ were about $200 \mathrm{~nm}$ (Fig. 5-A, bars), had spherical and homogeneous morphology (Fig. 5- $\mathrm{C}_{2}$ ), and the zeta potential value was higher (around $+30 \mathrm{mV}$ ) than the obtained with their counterparts lipid $\mathbf{1}$ and $\mathbf{2}$ (around + $20 \mathrm{mV}$, Fig. 5-A, lines). The higher superficial charge of niosomes based on the lipid $\mathbf{3}$ could explain the highest stability of this formation due to electrostatic repulsion forces that avoid variations over the time on size and zeta potential values, as observed on Fig. 6-B. Finally, nioplexes obtained upon the addition of DNA at different cationic lipid/DNA ratios (w/w), were more positively charged when the cationic lipid $\mathbf{3}$ was used (Fig. 7-B), which could support the data obtained in the agarose gel electrophoresis studies. According to this, only nioplexes formulated with the lipid $\mathbf{3}$ were able to condense, release and protect the DNA against enzymatic digestion at appropriate cationic lipid/DNA mass ratios 10/1, 20/1 and 30/1 (Fig. 8-B). All these data highlight that cationic lipid head groups play a relevant role on transfection efficiency, since minor structural changes are able to dramatically affect this process. However, not only transfection efficiency needs to be assessed when developing novel non-viral vector carriers for gene delivery purposes. The introduction of foreign DNA into the cell is not a 
natural process. Therefore, transfection is an inherent toxic process by itself. Additionally, cationic lipids toxicity is a highly cell dependent process that has been classically attributed to the induction of apoptosis and could limit the application in the clinic. ${ }^{53}$

Results related to cell viability are summarized in Fig. 9-B. We observed a clearly celldependent toxicity effect, being ARPE-19 the cells that better tolerated the nioplexes formulations at most ratio studied (with the exception lipid 3, ratio 30:1). Other reported cell viability studies performed with other niosomes based on a glycerol backbone instead of a serinol backbone have also shown that ARPE-19 cells tolerate the nioplexes better than HEK-293 cells. ${ }^{7}$ Cell-dependent toxicity effect observed could be probably due to differences in membrane composition as well as differences in phagocytic activity and processing of the nioplexes among the cells studied.

Regarding the cytotoxic effect among our three nioplexes formulations, we clearly observed that nioplexes based on the cationic lipid $\mathbf{3}$ had a more deleterious effect than their counterparts, especially in ARPE-19 cells at 20/1 and 30/1 ratios. This toxic effect of nioplexes based on the cationic lipid 3 could be explained by the higher zeta potential of these vectors, which could destabilize cell membranes.

To summarize, our data revealed that cationic lipid chemical structure of the hydrophilic group clearly influenced not only on transfection efficiency but also on cell viability. Therefore, the detailed study of this domain is a mandatory issue for the research community in order to design more efficient and safe non-viral vectors based on cationic lipids.

\section{CONCLUSION}

In the present study, we designed niosomes based on three different cationic lipids which differed only on the polar-head group. Our results show that the chemical composition of the cationic head-group clearly affects to the physicochemical parameters of the niosomes and specially, to the transfection efficiency. Only niosomes based on cationic lipids with a dimethyl amino head group (Lipid 3) showed transfection capacity when compared with their counterparts amino (Lipid 1) and tripeptide head-groups (Lipid 2). However, niosomes based on cationic lipid $\mathbf{3}$ showed a more deleterious effect than their counterpart lipids, especially in ARPE-19 cells at 20/1 and 30/1 ratios. Therefore, we hypothesize that changing the actual ether bond (linker domain) of cationic lipid $\mathbf{1}$ by a biodegradable ester bond could rend into better tolerated niosome formulations maintaining transfection efficiency, since ether bounds are too stable to be biodegraded, which results in higher toxicity compounds compared to ester bounds. ${ }^{54}$ In any case, further studies will be required to support this assumption.

\section{EXPERIMENTAL}

\subsection{Materials}

All reagents, solvents and chemicals used in this study were of the highest purity available and were used as received. DNase I, sodium dodecyl sulphate (SDS), squalene and PBS were purchased from Sigma-Aldrich (Madrid, Spain). Polysorbate 80 (Tween 80) was provided by Vencaser (Bilbao, Spain). All reactions were carried out under inert atmosphere of argon. Flash column chromatography was carried out on silica gel $S D S$ 
0.063-0.2 mm/70-230 mesh. ${ }^{1} \mathrm{H}$ and ${ }^{13} \mathrm{C}$ NMR spectra were recorded at $25^{\circ} \mathrm{C}$ on a Varian Mercury $400 \mathrm{MHz}$ spectrometer using deuterated solvents. Tetramethylsilane (TMS) was used as an internal reference $(0 \mathrm{ppm})$ for ${ }^{1} \mathrm{H}$ spectra recorded in $\mathrm{CDCl}_{3}$ and the residual signal of the solvent $(77.1 \mathrm{ppm})$ for ${ }_{13} \mathrm{C}$ spectra. For $\mathrm{CD}_{3} \mathrm{OD}$ and $\mathrm{d} 6-\mathrm{DMSO}$ the residual signal of the solvent was used as a reference. Chemical shifts are reported in part per million (ppm), coupling constants $(J)$ in $\mathrm{Hz}$ and multiplicity as follows: s (singlet), d (doublet), t (triplet), q (quadruplet), quint (quintuplet), m (multiplet) and br (broad signal). Electrospray ionization mass spectra (ESI-MS) were recorded on a Micromass ZQ instrument with single quadrupole detector coupled to an HPLC, and high-resolution (HR) ESI-MS on an Agilent 1100 LC/MS-TOF instrument (Servei d'Espectrometría de Masses, Universitat de Barcelona). Cell culture reagents were purchased from LGC Promochem (Barcelona, Spain). Opti-MEM ${ }^{\mathrm{TM}}$ I reduced medium, antibiotic/antimicotic solution and Lipofectamine ${ }^{\mathrm{TM}} 2000$ transfection reagents were acquired from Invitrogen (San Diego, California, USA). Retinal pigmented epithelial cells (ARPE-19), human embryonic kidney cells (HEK-293) and mouse bone marrow mesenchimal stem cells (MSC-D1) were obtained from the American Type Culture Collection (ATCC).

\subsection{Synthesis of cationic lipids}

\subsubsection{Synthesis of tert-butyl-N-[2-tetradecyloxy-1-(tetradecyloxymethyl)ethyl]carbamate} (5)

Diol 4 (500 mg; $2.61 \mathrm{mmol})$ and tetradecylalkyl bromide $(4.2 \mathrm{~mL}, 15.6 \mathrm{mmol})$ were dissolved in toluene $(2.0 \mathrm{~mL})$. Then, $\mathrm{Bu}_{4} \mathrm{NHSO}_{4}(444 \mathrm{mg} ; 1.305 \mathrm{mmol})$ was added along with a $50 \%$ solution of $\mathrm{NaOH}(3.0 \mathrm{~mL})$. The mixture was heated at $60{ }^{\circ} \mathrm{C}$ with vigorous stirring overnight. The reaction was diluted with AcOEt $(15 \mathrm{~mL})$ and the organic layer was washed with water $(3 \times 10 \mathrm{~mL})$. The organic layer was dried on anhydrous $\mathrm{MgSO}_{4}$ and solvent was evaporated obtaining the corresponding crude that was purified by flash chromatography (Hex $100 \%$ to Hex/AcOEt $10 \%$ ).

Yield 54\%; ${ }^{1} \mathrm{H}$-NMR (400 MHz, $\left.\mathrm{CDCl}_{3}\right) \delta 4.89$ (broad s, NH), 3.50 (m, 1H;CH-N), 3.41 (m, 8H; $\left.4 \mathrm{CH}_{2}-\mathrm{O}\right), 1.54$ (s, 9H; $\left.3 \mathrm{CH}_{3}-\mathrm{C}\right), 1.44(\mathrm{~s}, 9 \mathrm{H} ; 3 \mathrm{CH}-\mathrm{C}), 1.28$ (m, 48H; alkyl chain), 0.88 (t, $\left.J=6.7 \mathrm{~Hz}, 6 \mathrm{H} ; 2 \mathrm{CH}_{3}\right)$; The spectra shows rotamers; ${ }^{13} \mathrm{C}-\mathrm{NMR}(125 \mathrm{MHz}$, $\left.\mathrm{CDCl}_{3}\right) \delta 146.7(\mathrm{CO}), 85.1(\mathrm{C}-\mathrm{O}), 71.3\left(\mathrm{CH}_{2}-\mathrm{O}\right), 69.1\left(\mathrm{CH}_{2}-\mathrm{O}\right), 31.8(\mathrm{CH}-\mathrm{N}), 29.7,29.6$, 29.6, 29.4, 29.3, 28.3, 27.3, 26.1, 22.6 (alkyl chain), $14.0\left(\mathrm{CH}_{3}\right)$; ESI-MS for $\mathrm{C}_{36} \mathrm{H}_{74} \mathrm{NO}_{4}$ $\mathrm{m} / \mathrm{z} 584.5612$ (calculated) $584.5608(\mathrm{M}+\mathrm{H})+\left(\right.$ found); $\mathrm{C}_{72} \mathrm{H}_{146} \mathrm{~N}_{2} \mathrm{NaO} 8 \mathrm{~m} / \mathrm{z} 1190.0971$ (calculated) $1190.0974(2 \mathrm{M}+\mathrm{Na})+$ (found).

\subsubsection{Synthesis of 1,3-di(tetradecyloxy)propan-2-amine (Lipid 1)}

$\mathrm{N}$-protected alkyl diol 5 (300 mg; $0.514 \mathrm{mmol})$ was dissolved in a mixture of dichloromethane: trifluoroacetic acid $(4: 0.5 ; \mathrm{v} / \mathrm{v})$. The reaction was stirred at room temperature for 30 minutes. The solvent was evaporated obtaining the corresponding amine derivative in its trifluoroacetate form. The crude was re-dissolved in AcOEt (5 $\mathrm{mL}$ ) and carbonate on polymer support (20 eq) was added. Mixture was stirred for 1 hour at room temperature. The resin was filtered off and the solvent was evaporated, obtaining the expected Lipid 1 which was used without further purification.

Yield 100\%; ${ }^{1} \mathrm{H}$-NMR (400 MHz, $\left.\mathrm{CDCl}_{3}\right) \delta 3.43\left(\mathrm{~m}, 6 \mathrm{H} ; 3 \mathrm{CH}_{2}-\mathrm{O}\right) ; 3.30$ (m, 2H; $\mathrm{CH}_{2}-$ $\mathrm{O}) ; 3.15$ (m, 1H; CH-N); $1.26\left(\mathrm{~m}, 48 \mathrm{H}\right.$; alkyl chain); 0.88 (t, $\left.J=6.7 \mathrm{~Hz} ; 6 \mathrm{H} ; 2 \mathrm{CH}_{3}\right)$; 
${ }^{13} \mathrm{CNMR}\left(125 \mathrm{MHz}, \mathrm{CDCl}_{3}\right) \delta 71.9\left(\mathrm{CH}_{2}-\mathrm{O}\right), 66.7\left(\mathrm{CH}_{2}-\mathrm{O}\right), 51.8\left(\mathrm{CH}_{2}-\mathrm{O}\right), 31.8(\mathrm{CH}-\mathrm{N})$, 29.7, 29.6, 29.6, 29.5, 29.3, 29.3, 29.1, 25.8, 22.6 (alkyl chain), 14.0 ( $\left.\mathrm{CH}_{3}\right)$; ESI-MS for $\mathrm{C}_{31} \mathrm{H}_{65} \mathrm{NO}_{2} \mathrm{~m} / \mathrm{z} 484.5135$ (calculated) $484.5136(\mathrm{M}+\mathrm{H})_{+}$(found).

4.2.3. Synthesis of tert-butyl-N-[2-oxo-2-[[2-oxo-2-[[2-oxo-2-[[2-tetradecyloxy-1(tetradecyloxymethyl)-ethyl]amino]ethyl]amino]ethyl]amino]ethyl]carbamate (6)

Previously, Boc-triglycine ( $2.0 \mathrm{eq}$ ) and $N$-hydroxysuccinimide (2.2 eq) were dissolved in dichloromethane $(3 \mathrm{~mL})$. Reaction was stirred for 5 minutes and EDC $(2.4 \mathrm{eq})$ was added. The reaction was stirred overnight at room temperature. The organic layer was washed with water $(3 \times 5 \mathrm{~mL})$ and dried over anhydrous $\mathrm{MgSO}_{4}$. The solvent was evaporated and crude was used in the next step without further purification. Amine alkyl diol $\mathbf{3}(100 \mathrm{mg}$; $0.206 \mathrm{mmol}$ ) was added over the activated tripeptide. Reaction was heated at $60{ }^{\circ} \mathrm{C}$ and stirred overnight. The solvent was evaporated and the resultant crude was purified by flash chromatography (DCM/MeOH 5\%).

Yield $86 \%,{ }^{1} \mathrm{H}-\mathrm{NMR}\left(400 \mathrm{MHz}, \mathrm{CDCl}_{3}\right) \delta 7.04$ (broad m, NH), 6.04 (broad d, NH), 5.54 (broad s, NH), 4.18 (broad s, NH), $3.99\left(\mathrm{~d}, J=5.7 \mathrm{~Hz}, 2 \mathrm{H} ; \mathrm{CH}_{2}\right), 3.90(\mathrm{~d}, J=5.7 \mathrm{~Hz}, 2 \mathrm{H}$; $\left.\mathrm{CH}_{2}\right), 3.83\left(\mathrm{~d}, J=5.7 \mathrm{~Hz}, 2 \mathrm{H} ; \mathrm{CH}_{2}\right), 3.51\left(\mathrm{~m}, 4 \mathrm{H} ; 2 \mathrm{CH}_{2}-\mathrm{O}\right), 3.42(\mathrm{~m}, 5 \mathrm{H} ; \mathrm{CH}-\mathrm{N}$ and 2 $\left.\mathrm{CH}_{2}-\mathrm{O}\right), 2.39$ (t, $\left.J=5.9 \mathrm{~Hz}, 2 \mathrm{H}\right), 1.54\left(\mathrm{~m}, 4 \mathrm{H} ; 2 \mathrm{CH}_{2}\right), 1.44$ (s, 9H; $\left.3 \mathrm{CH}_{3}-\mathrm{C}\right) ; 1.26(\mathrm{~m}$, $44 \mathrm{H}$; alkyl chain), $0.88\left(\mathrm{t}, J=7.0 \mathrm{~Hz}, 6 \mathrm{H} ; 2 \mathrm{CH}_{3}\right) ;{ }^{13} \mathrm{C}-\mathrm{NMR}\left(125 \mathrm{MHz}, \mathrm{CDCl}_{3}\right) \delta 168.5$ (CO), $166.8(\mathrm{CO}), 165.7(\mathrm{CO}), 164.7(\mathrm{CO}), 76.2(\mathrm{C}-\mathrm{O}), 67.4\left(\mathrm{CH}_{2}-\mathrm{O}\right), 64.7\left(\mathrm{CH}_{2}-\mathrm{O}\right)$, $49.7\left(\mathrm{CH}_{2}-\mathrm{N}\right), 44.9\left(\mathrm{CH}_{2}-\mathrm{N}\right), 39.0\left(\mathrm{CH}_{2}-\mathrm{N}\right), 38.9(\mathrm{CH}-\mathrm{N}), 27.9\left(\mathrm{CH}_{3}-\mathrm{C}\right), 25.8,25.7,25.6$, 25.5, 25.3, 24.3, 22.0, 21.4, 18.7, 14.5, 13.4, 10.1, 7.8 (alkyl chain); ESI-MS for $\mathrm{C}_{42} \mathrm{H}_{82} \mathrm{~N}_{4} \mathrm{O}_{7} \mathrm{~m} / \mathrm{z} 755.6256$ (calculated) $755.6260(\mathrm{M}+\mathrm{H})_{+}, \mathrm{C}_{42} \mathrm{H}_{82} \mathrm{~N}_{4} \mathrm{NaO}_{7} 777.6072$ (calculated) $777.6076(\mathrm{M}+\mathrm{Na})+\mathrm{C}_{84} \mathrm{H}_{164} \mathrm{~N}_{8} \mathrm{NaO}_{14} \quad 1532.2251$ (calculated) 1532.2251 $(2 \mathrm{M}+\mathrm{Na})+($ found $)$.

\subsubsection{Synthesis of [[2-[(2-aminoacetyl)amino]acetyl]amino]-N-[2-tetradecyloxy- 1(tetradecoxymethyl)-ethyl]-acetamide (Lipid 2)}

Boc-protected alkyl tripeptide $\mathbf{6}(70 \mathrm{mg}$; $0.093 \mathrm{mmol})$ was dissolved in a mixture of $10 \%$ trifluoroacetic acid in dichloromethane. The reaction was stirred at room temperature for one hour. Solvent was removed until dryness. The corresponding trifluoroacetate salt was dissolved in a mixture of AcOEt: $\mathrm{MeOH}$ (3:2) and carbonate on polymer support (20 eq) was added. The reaction was stirred for one hour at room temperature. The resin was filtered off and solvent was evaporated obtaining the corresponding Lipid 2 which was used without further purification.

Yield 100\%, ${ }^{1} \mathrm{H}-\mathrm{NMR}\left(400 \mathrm{MHz}, \mathrm{CDCl}_{3}\right) \delta 7.97$ (broad s, NH), 7.14 (broad s, NH), 6.27 (broad d, NH), 4.09 (broad s, $\mathrm{NH}_{2}$ ), $3.92\left(\mathrm{~m}, 2 \mathrm{H} ; \mathrm{CH}_{2}-\mathrm{N}\right), 3.84\left(\mathrm{~m}, 2 \mathrm{H} ; \mathrm{CH}_{2}-\mathrm{N}\right), 3.44$ (m, $\left.2 \mathrm{H} ; \mathrm{CH}_{2}-\mathrm{N}\right), 3.34$ (m, 8H; $\left.4 \mathrm{CH}_{2}-\mathrm{O}\right), 1.46\left(\mathrm{~m}, 2 \mathrm{H} ; \mathrm{CH}_{2}-\mathrm{C}\right), 1.18$ (m, 44H; alkyl chain), $0.80\left(\mathrm{t}, \mathrm{J}=6.8 \mathrm{~Hz}, 6 \mathrm{H} ; 2 \mathrm{CH}_{3}\right) ;{ }^{13} \mathrm{C}-\mathrm{NMR}\left(125 \mathrm{MHz}, \mathrm{CDCl}_{3}\right) \delta 173.7(\mathrm{CO}), 169.3(\mathrm{CO})$, $168.2(\mathrm{CO}), 71.5\left(\mathrm{CH}_{2}-\mathrm{O}\right), 68.8\left(\mathrm{CH}_{2}-\mathrm{O}\right), 48.9\left(\mathrm{CH}_{2}-\mathrm{NH}_{2}\right), 42.8\left(\mathrm{CH}_{2}-\mathrm{N}\right), 31.9\left(\mathrm{CH}_{2}-\mathrm{N}\right)$, 29.7 (CH-N), 29.6, 29.5, 29.5, 29.4, 29.3, 26.0, 22.6 (alkyl chain), $14.0\left(\mathrm{CH}_{3}-\mathrm{C}\right)$; ESI-MS for $\mathrm{C}_{37} \mathrm{H}_{74} \mathrm{~N}_{4} \mathrm{O}_{5} \mathrm{~m} / \mathrm{z} 655.5732$ (calculated) $655.5731(\mathrm{M}+\mathrm{H})_{+}$(found).

4.2.5 Synthesis of 1-(2-dimethylaminoethyl)-3-[2-tetradecyloxy-1-(tetradecoxymethyl)ethyl]urea (Lipid 3) 
Previously, $p$-nitrophenyl-chloroformate (2.5 eq) and the di-alkylated amine 1 (50 mg; $0.103 \mathrm{mmol})$ were dissolved in a mixture of tetrahydrofurane and dichloromethane $(1: 1)$ ( $3 \mathrm{~mL}$ ). The reaction was cooled at $0{ }^{\circ} \mathrm{C}$ and DIEA (2.5 eq) was carefully added dropwise. The solution was heated at room temperature and stirred for 4 hours. The solvent was removed and the resultant crude was used in the next step without further purification. Crude was dissolved in DMF (3 mL) and the corresponding amine derivative (1.1 eq) was added dropwise. The reaction was stirred overnight at room temperature. Finally, solvent was removed and the resultant crude was purified by flash chromatography (DCM: $\mathrm{MeOH} 5 \%$ to $10 \%$ ) obtaining the expected Lipid 3.

Yield 88\%, ${ }^{1} \mathrm{H}-\mathrm{NMR}\left(400 \mathrm{MHz}, \mathrm{CDCl}_{3}\right) \delta 5.03$ (broad s, NH), 4.98 (broad s, NH), 3.52 $(\mathrm{d}, J=4.4 \mathrm{~Hz}, 1 \mathrm{H} ; \mathrm{CH}-\mathrm{NH}), 3.50(\mathrm{~d}, J=4.4 \mathrm{~Hz}, 1 \mathrm{H} ; \mathrm{CH}-\mathrm{NH}), 3.42\left(\mathrm{~m}, 8 \mathrm{H} ; 4 \mathrm{CH}_{2}-\mathrm{O}\right)$, $3.25\left(\mathrm{~m}, 2 \mathrm{H} ; \mathrm{CH}_{2}-\mathrm{N}\right), 2.44\left(\mathrm{t}, J=5.9 \mathrm{~Hz}, 2 \mathrm{H} ; \mathrm{CH}_{2}-\mathrm{N}\right), 2.26\left(\mathrm{~s}, 6 \mathrm{H} ; 2 \mathrm{CH}_{3}-\mathrm{N}\right), 1.54(\mathrm{~m}$, 4H; $2 \mathrm{CH}_{2}$ ), 1.27 (m, 44H; alkyl chain); 0.88 (t, $\left.J=6.7 \mathrm{~Hz}, 6 \mathrm{H} ; 2 \mathrm{CH}_{3}\right) ;{ }^{13} \mathrm{C}-\mathrm{NMR}(125$ $\left.\mathrm{MHz}_{\mathrm{CDCl}}\right) \delta 158.1(\mathrm{CO}), 71.3(\mathrm{CH}-\mathrm{N}), 69.8\left(\mathrm{CH}_{2}-\mathrm{O}\right), 58.8\left(\mathrm{CH}_{2}-\mathrm{O}\right), 49.6\left(\mathrm{CH}_{2}-\mathrm{N}\right)$, $45.0\left(\mathrm{CH}_{2}-\mathrm{N}\right), 37.8\left(\mathrm{CH}_{3}-\mathrm{N}\right), 31.9,29.7,29.6,29.5,29.3,26.1,22.6,14.0\left(\mathrm{CH}_{3}\right)$. The spectra shows rotamers; ESI-MS for $\mathrm{C}_{36} \mathrm{H}_{75} \mathrm{~N}_{3} \mathrm{O} 3 \mathrm{~m} / \mathrm{z} 598.5881$ (calculated) 598.5888 $(\mathrm{M}+\mathrm{H})^{+}$(found).

\subsection{Small Angle X-ray Scattering (SAXS) analysis of cationic lipids}

SAXS patterns were recorded simultaneously using a S3-MICRO (Hecus X-ray systems GMBH Graz. Austria) coupled to a GENIX-Fox 3D X-ray source (Xenox. Grenoble) which produces a detector-focused X-ray beam with $\lambda=0.1542 \mathrm{~nm} \mathrm{Cu} \mathrm{K}$-line at greater than $97 \%$ purity and less than $0.3 \% \mathrm{~K}_{\alpha}$. The transmitted scattering was detected using a PSD 50 Hecus at small-angle regime $\left(0.09 \mathrm{~nm}^{-1}<\mathrm{q}<6 \mathrm{~nm}^{-1}\right)$. Temperature was controlled through a Peltier TCCS-3 Hecus. The dry lipid samples (5 - $10 \mathrm{mg}$ ) were inserted in a glass capillary with $1 \mathrm{~mm}$ diameter and $20 \mu \mathrm{m}$ wall thickness (Hilgenberg, Germany) and HEPES buffer was added and mixed with the lípid derivatives. The capillaries were incubated at $25^{\circ} \mathrm{C}$ and $37^{\circ} \mathrm{C}$ for $24 \mathrm{~h}$ at least. The SAXS scattering curves were plotted as a function of the scattering vector modulus, $q=4 \pi / \lambda \sin (\theta / 2)$, where $\theta$ is the scattering angle and $\lambda$ the wavelength of the incident radiation. The system scattering vector was calibrated by measuring a standard silver behenate sample. Scattering curves were mainly smeared by the detector width because we used a detectorfocused small beam ( $300 \times 400 \mu \mathrm{m}$ full width at half maximum), which widens the peaks without a noticeable effect on peak position. The instrumentally smeared experimental SAXS curves were fitted to numerically smeared models for beam size and detector width effects. A least squares routine based on the Levenberg-Marquardt scheme was used. The bilayer was fitted using a three-Gaussian profile based on the MCG model. ${ }^{20,21}$

Specifically, the bilayer is calculated as a summation of the head-groups contribution (in the form of a Gaussian centred at $\pm Z_{h}$, amplitude $\sigma_{h}$ and maximum contrast electron density $\left.\tilde{\rho}_{H}=\left(\rho_{H}-\rho_{H_{2} O}\right)\right)$, the methyl groups contribution (in the form of a Gaussian centred at 0 with amplitude $\sigma_{c}$ and maximum electron density $\left.\tilde{\rho}_{C}=\left(\rho_{C}-\rho_{\mathrm{H}_{2} \mathrm{O}}\right)\right)$. In addition to these two contributions and, as a difference with the original model reported by Pabst et al., ${ }^{20}$ a third contribution corresponding to an error function centred at the bilayer centre and negative contrast electron density contribution 
$\tilde{\rho}_{\mathrm{CH}_{2}}=\left(\rho_{\mathrm{CH}_{2}}-\rho_{\mathrm{H}_{2} \mathrm{O}}\right)$ corresponding to the difference in electron density between the bilayer methylene and the outer water. ${ }^{19}$

$\rho(Z)=\tilde{\rho}_{H} \exp \left[\left(-Z-Z_{H}\right)^{2} / 2 \sigma_{H}^{2}\right]+\tilde{\rho}_{C} \exp \left[(-Z)^{2} / 2 \sigma_{C}^{2}\right]+\rho_{C_{2}}(Z)$

where the methylene contributions is a mirrored error function centred at the polar/non polar interface,

$\rho_{\mathrm{CH}_{2}}(z>0)=\tilde{\rho}_{\mathrm{CH}_{2}} \frac{1}{\sqrt{\pi}} \int_{Z}^{\infty} e^{-\left(t-Z_{\mathrm{CH}_{2}}\right)^{2}} d t$

The unidimensional Fourier transform of the corresponding electronic profile has been numerically evaluated. The structure is modelled according to the modified Caille model as in Pabst et al..$^{20}$ (eqn (3)) and the global intensity is calculated according to equation 4, where $N_{\text {diff }}$ corresponds to a fraction of uncorrelated bilayers.

$$
\begin{aligned}
& S(q)=N+2 \sum_{k=1}^{N-1}(N-k) \cos (k q d) e^{-(d / 2 \pi)^{2} q^{2} \eta_{1} \gamma}(\pi k)^{-(d / 2 \pi)^{2} q^{2} \eta_{1}} \\
& I(q)=\left|F(q)^{2} S(q)\right| / q^{2}
\end{aligned}
$$

The parameters in eqn (3) correspond to $N$, total number of correlated bilayers, $d$ repetition distance, $\eta_{1}$ the Caillé parameter and $\gamma$ to the Euler constant.

\subsection{Preparation of niosomes}

Niosomes based on three different synthetic cationic lipids were prepared using both the $\mathrm{o} / \mathrm{w}$ emulsification and the film-hydration techniques. In the o/w emulsification technique,

$5 \mathrm{mg}$ of the cationic lipid were gently grinded with $20 \mu \mathrm{l}$ of squalene to obtain a fine powder. Then, $1 \mathrm{ml}$ of dichloromethane was quickly added and emulsified with $5 \mathrm{ml}$ aqueous phase containing non-ionic surfactant polysorbate $80(0.5 \%, \mathrm{w} / \mathrm{w})$. The emulsion was obtained by sonication (Branson Sonifier 250, Danbury) during $60 \mathrm{~s}$ at $50 \mathrm{~W}$ in ice bath. The organic solvent was removed from the emulsion by evaporation under magnetic agitation for $4 \mathrm{~h}$. Upon dichloromethane evaporation, a dispersion containing the nanoparticles was formed by precipitation of the cationic nanoparticles in the aqueous medium. In the Film-Hydration technique, $5 \mathrm{mg}$ of the cationic lipid were gently grinded with $20 \mu \mathrm{l}$ of squalene to obtain a fine powder. Then, $1 \mathrm{ml}$ of dichloromethane was added and thoroughly mixed to obtain the organic phase. Then, the solvent was evaporated under magnetic agitation for $4 \mathrm{~h}$. Under DCM evaporation, the lipid film obtained was hydrated with $5 \mathrm{ml}$ aqueous phase containing non-ionic surfactant polysorbate $80(0.5 \%$, w/w). The emulsion was obtained by sonication (Branson Sonifier 250, Danbury) during $60 \mathrm{~s}$ at $50 \mathrm{~W}$ in ice bath. We obtained the same niosome concentration using both techniques (1mg cationic lipid/ml). 


\subsection{Plasmid propagation and preparation of nioplexes}

pCMS-EGFP plasmid was propagated in Escherichia coli DH5- $\alpha$ and purified using the Qiagen endotoxin-free plasmid purification Maxi-prep kit (Qiagen, Santa Clarita, CA, USA) according to the manufacturer's instructions. Concentration of pDNA was quantified by measuring absorbance at $260 \mathrm{~nm}$ using a NanoDrop® (ND-1000 Spectrophotometer, Thermo Fisher Scientific Inc. Denver, USA). The purity of the plasmid was verified by agarose gel electrophoresis in Tris Borate-EDTA buffer, $\mathrm{pH} 8.0$ (TBE buffer). DNA bands were detected using GelRed ${ }^{\mathrm{TM}}$ (Biotium, Hayward, California, USA) to stain DNA and images were observed with a ChemiDoc ${ }^{\mathrm{TM}}$ MP Imaging System (Bio-Rad, USA).

The nioplexes (Niosome/DNA vectors) were elaborated by mixing an appropriate volume of a stock solution of pCMS-EGFP plasmid $(0.5 \mathrm{mg} / \mathrm{ml})$ with different volumes of the niosome suspensions ( $1 \mathrm{mg}$ cationic lipid/ml). The mixture was left for $30 \mathrm{~min}$ at room temperature to enhance electrostatic interaction between the cationic lipids of the niosomes and the negatively charged plasmid. The Niosome/DNA ratio was referred as the ratio of cationic lipid to DNA (w/w). The stock solutions of cationic lipid $(1 \mathrm{mg} / \mathrm{ml})$ corresponds to the following molar concentrations : $2.07 \mathrm{mM}$ (Lipid 1, MW 484), 1.53 $\mathrm{mM}$ (Lipid 2, MW 655), and $1.67 \mathrm{mM}$ (Lipid 3, MW 598). The stock solution of plasmid pCMS-EGFP of $0.5 \mathrm{mg} / \mathrm{ml}$ was estimated to be around 0.137 micromolar (pCMS-EGFP, $5541 \mathrm{bp}$, average MW 3657060).

\subsection{TNS fluorescence titration assay for the determination of the pka value of the niosomes}

Fluorescent measures were recorded on a SpectraMax M5 spectrophotometer (Molecular

Devices) with the excitation wavelength $\left(\lambda_{\mathrm{ex}}\right)$ set at $321 \mathrm{~nm}$ and the emission wavelength

$\left(\lambda_{\mathrm{em}}\right)$ set at $445 \mathrm{~nm}$. Niosomes were diluted to $75 \mu \mathrm{M}$ cationic lipids $(\mathbf{1}, \mathbf{2}$ and $\mathbf{3})$ in 100 $\mu \mathrm{L}$ of buffer solutions containing $10 \mathrm{mM}$ HEPES, $10 \mathrm{mM}$ MES, $10 \mathrm{mM}$ ammonium acetate and $150 \mathrm{mM} \mathrm{NaCl}$ with $\mathrm{pH}$ ranging between 2.5 and 11.1. A stock solution of TNS dissolved in DMSO was added to the above buffer solution to obtain a $1 \mu \mathrm{M}$ TNS solution. Solutions were mixed thoroughly and the resultant fluorescence was measured at room temperature. Fluorescence values are results from triplicate measurements. The fluorescence of TNS (normalized) was plotted against $\mathrm{pH}$. Curves were fitted using a sigmoid function. The pka values of the cationic lipids were calculated as the $\mathrm{pH}$ values at which TNS fluorescence is half-maximal fluorescence intensity.

\subsection{Size and zeta potential measurements}

The hydrodynamic diameter of the niosomes and nioplexes were determined by Dynamic Light Scattering (DLS) using a Zetasizer Nano ZS (Malvern Instrument, UK). Briefly, 50 $\mu \mathrm{l}$ of the niosomes or nioplexes were resuspended into $950 \mu \mathrm{l}$ of $0.1 \mathrm{mM} \mathrm{NaCl}$ solution to determined size and PDI. All measurements were carried out in triplicate. The particle size reported as hydrodynamic diameter was obtained by cumulative analysis.

The zeta potential was obtained by Lasser Doppler Velocimetry (LDV) using a Zetasizer Nano ZS (Malvern Instrument, UK). Samples were resuspended $(50 \mu \mathrm{l})$ into $0.1 \mathrm{mM}$ $\mathrm{NaCl}(950 \mu \mathrm{l})$ using folded capillary cells for zeta analysis. The Smoluchowski approximation was used to support the calculation of the zeta potential from the 
electrophoretic mobility. Zeta potential measurements were run in triplicate. Only data that met the quality criteria according with the software program (DTS 5.0) were included in the study.

\subsection{Cryo-TEM microscopy of niosomes}

The morphology of niosomes was observed by Cryo-TEM microscopy. Briefly, one drop of the sample solution was vitrified by rapid freezing in liquid ethane using a Vitrobot Markt IV (FEI). This vitrified sample grid was transferred through 655 Turbo Pumping Station (Gatan) to a 626 DH Single Tilt Liquid Nitrogen Cryo-holder (Gatan), where was maintained about $-180^{\circ} \mathrm{C}$. Copper grid (300 mesh Quantifoils) was hydrophilized by glow-discharge treatment. The sample was examined in a TEM, TECNAI G2 20 TWIN (FEI), operating at an accelerating voltage of $200 \mathrm{KeV}$ in a bright-field and low-dose image mode.

\subsection{Physical stability study of niosomes}

The physical stability of niosomes based on three different synthetic cationic lipids was determined by monitoring the particle size and zeta potential after storage for 100 days at $4^{\circ} \mathrm{C}$ and $25^{\circ} \mathrm{C}$. All samples were measure in triplicate.

\subsection{Agarose gel electrophoresis studies of nioplexes}

Naked DNA or nioplexes at different ratios (20 $\mu$ l, containing $200 \mathrm{ng}$ of the plasmid) were subjected to electrophoresis on an agarose gel $(0.8 \%)$. The gel was immersed in a tris-acetate-EDTA buffer and exposed for $30 \mathrm{~min}$ to $120 \mathrm{~V}$. DNA bands were stained with GelRed $^{\mathrm{TM}}$ (Biotium, Hayward, California, USA) and images were observed with a TFX-20M transilluminator (Vilber-Lourmat, Germany). To analyze the release of DNA from the formulation, $12 \mu \mathrm{l}$ of a $7 \%$ SDS solution was added to the samples to get a final SDS concentration of $3.5 \%$ in each well. The pDNA protection capacity of the vectors against enzymatic digestion was analyzed by adding the DNase I enzyme to the vector formulations (final concentration of $1 \mathrm{U}$ DNase $\mathrm{I} / 2.5 \mu \mathrm{g}$ DNA).

Afterwards, the mixtures were incubated at $37^{\circ} \mathrm{C}$ for $30 \mathrm{~min}$ and finally, $12 \mu \mathrm{l}$ of a $7 \%$ SDS solution was added to analyze the released DNA. The integrity of the DNA in each sample was compared to a control of untreated DNA.

\subsection{Cell culture and in vitro transfection protocols}

HEK-293, ARPE-19 and MSC-D1 cells were seeded in 24 well plates at an initial density of $15 \times 10^{4}, 10 \times 10^{4}$, and $8 \times 10^{4}$ cells/well, with $300 \mu$ of EMEM containing $10 \%$ horse serum, $300 \mu \mathrm{l}$ of D-MEM/F-12 containing 10\% bovine serum, and $300 \mu \mathrm{l}$ of DEMEM containing 10\% horse serum, respectively. Cells were adhered overnight to reach $70-90 \%$ of confluence at the time of transfection. Then, the regular growth medium was removed and the cells were exposed to nioplexes resuspended in Opti-MEM ${ }^{\circledR}$ transfection medium at different cationic lipid/DNA ratios, containing all of them $1.25 \mu \mathrm{g}$ of the plasmid. Each formulation was used in triplicate. After $4 \mathrm{~h}$ of incubation at $37^{\circ} \mathrm{C}$, the nioplexes were replaced by $500 \mu \mathrm{l}$ of regular growth medium. Cells were allowed to grow for $72 \mathrm{~h}$ until flow cytometry analysis. Following the manufacturer's protocol, lipofectamine ${ }^{\mathrm{TM}} 2000$ was used in combination with pDNA, as transfection positive control. 


\subsection{Transfection efficiency and cell viability measurement}

Flow cytometry analysis was conducted using a FACSCalibur system flow cytometer (Becton Dickinson Bioscience, San Jose, USA) in order to quantify the \% of EGFP positive cells. Cells were washed twice in PBS and detached from the microplate with $200 \mu \mathrm{l}$ of trypsin/EDTA and $400 \mu \mathrm{l}$ of normal growth medium were added. The pellets were resuspended in growth medium, diluted in FACSFlow liquid and directly introduce to the flow cytometer. Transfection efficiency was expressed as the percentage of EGFP positive cells at $525 \mathrm{~nm}\left(\mathrm{FL}_{1}\right)$. Control samples (non-transfected cells) were displayed on a forward scatter (FCS) versus side scatter (SSC), dot plot to establish a collection gate and exclude cell debris. Other examples containing Lipofectamine transfected cells, and non-transfected cells were used as controls to compensate $\mathrm{FL}_{2}$ signal in $\mathrm{FL}_{1}$ channels. For each sample 10,000 events were collected.

Cell viability of the three cell lines was evaluated using the Cell Counting Kit-8 (CCK-8; Dojingo Molecular Technologies, Inc, Gaithersburg, MD) according with the manufacturer's protocol. Briefly, cells were exposed to nioplexes under the same conditions as described before. $72 \mathrm{~h}$ later, $10 \mu \mathrm{l}$ of CCK- 8 solution was added to $200 \mu \mathrm{l}$ of medium in each well, and the plate was incubated $4 \mathrm{~h}$ at $37^{\circ} \mathrm{C}$ and $5 \% \mathrm{CO}_{2}$. Relative cell viability percentage (\%) was calculated based on the absorbance (Infinite M200 microplate reader, Tecan GENios, Switzerland) observed at $450 \mathrm{~nm}$. Each formulation was used in triplicate.

\section{ACKNOWLEDGMENTS}

This project was partially supported by the University of the Basque Country UPV/EHU (UFI 11/32), the National Council of Science and Technology (CONAYT), Mexico, Reg. \# 217101, the Spanish Ministry of Education (Grant CTQ2010-20541, CTQ2010-14897), the Basque Government (Department of Education, University and Research, predoctoral BFI-2011-2226 grant), the Generalitat de Catalunya (2009SGR208, 2009SGR1331) and the Instituto de Salud Carlos III. Technical and human support provided by SGIker (UPV/EHU) is gratefully acknowledged. Authors also wish to thank the intellectual and technical assistance from the platform for Drug Formulation (NANBIOSIS) CIBER-BBN.

\section{REFERENCES}

1. W. F. Anderson, Nature, 1998, 392, 25-30.

2. A. del Pozo-Rodriguez, S. Pujals, D. Delgado, M. A. Solinis, A. R. Gascon, E. Giralt and J. L. Pedraz, J Control Release, 2009, 133, 52-59.

3. I. M. Verma, Mol Ther, 2000, 2, 415-416.

4. P. Charbel Issa and R. E. MacLaren, Clin Experiment Ophthalmol, 2012, 40, 39-47.

5. R. Rajera, K. Nagpal, S. K. Singh and D. N. Mishra, Biol Pharm Bull, 2011, 34, 945953.

6. D. Paolino, R. Muzzalupo, A. Ricciardi, C. Celia, N. Picci and M. Fresta, Biomed Microdevices, 2007, 9, 421-433.

7. G. Puras, M. Mashal, J. Zarate, M. Agirre, E. Ojeda, S. Grijalvo, R. Eritja, A. DiazTahoces, G. Martinez Navarrete, M. Aviles-Trigueros, E. Fernandez and J. L. Pedraz, J Control Release, 2014, 174, 27-36.

8. F. Liu, J. Yang, L. Huang and D. Liu, Pharm Res, 1996, 13, 1642-1646. 
9. H. Chung, T. W. Kim, M. Kwon, I. C. Kwon and S. Y. Jeong, J Control Release, 2001, 71, 339-350.

10. Y. Huang, Y. Rao, J. Chen, V. C. Yang and W. Liang, J Biomed Mater Res A, 2011, 96, 513-519.

11. B. Ma, S. Zhang, H. Jiang, B. Zhao and H. Lv, J Control Release, 2007, 123, 184-194. 12. G. Byk, C. Dubertret, V. Escriou, M. Frederic, G. Jaslin, R. Rangara, B. Pitard, J. Crouzet, P. Wils, B. Schwartz and D. Scherman, J Med Chem, 1998, 41, 229-235.

13. Y. V. Mahidhar, M. Rajesh and A. Chaudhuri, J Med Chem, 2004, 47, 3938-3948.

14. D. Zhi, S. Zhang, B. Wang, Y. Zhao, B. Yang and S. Yu, Bioconjug Chem, 2010, 21, 563-577.

15. P. P. Karmali and A. Chaudhuri, Med Res Rev, 2007, 27, 696-722.

16. F. Zhao, G. Shen, C. Chen, R. Xing, Q. Zou, G. Ma and X. Yan, Chemistry, 2014, 20, 6880-6887.

17. K. Wang, X. Yan, Y. Cui, Q. He and J. Li, Bioconjug Chem, 2007, 18, 1735-1738.

18. X. Yan, J. Li and H. Mohwald, Adv Mater, 2012, 24, 2663-2667.

19. N. Kucerka, M. P. Nieh and J. Katsaras, Langmuir, 2009, 25, 13522-13527.

20. G. Pabst, M. Rappolt, H. Amenitsch and P. Laggner, Phys Rev E Stat Phys Plasmas Fluids Relat Interdiscip Topics, 2000, 62, 4000-4009.

21. E. Haba, A. Pinazo, R. Pons, L. Perez and A. Manresa, Biochim Biophys Acta, 2014, 1838, 776-783.

22. R. Kanasty, J. R. Dorkin, A. Vegas and D. Anderson, Nat Mater, 2013, 12, 967-977. 23. S. C. Semple, A. Akinc, J. Chen, A. P. Sandhu, B. L. Mui, C. K. Cho, D. W. Sah, D. Stebbing, E. J. Crosley, E. Yaworski, I. M. Hafez, J. R. Dorkin, J. Qin, K. Lam, K. G. Rajeev, K. F. Wong, L. B. Jeffs, L. Nechev, M. L. Eisenhardt, M. Jayaraman, M. Kazem, M. A. Maier, M. Srinivasulu, M. J. Weinstein, Q. Chen, R. Alvarez, S. A. Barros, S. De, S. K. Klimuk, T. Borland, V. Kosovrasti, W. L. Cantley, Y. K. Tam, M. Manoharan, M. A. Ciufolini, M. A. Tracy, A. de Fougerolles, I. MacLachlan, P. R. Cullis, T. D. Madden and M. J. Hope, Nat Biotechnol, 2010, 28, 172-176.

24. J. Zhang, H. Fan, D. A. Levorse and L. S. Crocker, Langmuir, 2011, 27, 1907-1914.

25. C. Tros de Ilarduya, Y. Sun and N. Duzgunes, Eur J Pharm Sci, 2010, 40, 159-170.

26. G. Caracciolo, R. Caminiti, M. A. Digman, E. Gratton and S. Sanchez, J Phys Chem B, 2009, 113, 4995-4997.

27. G. Caracciolo and H. Amenitsch, Eur Biophys J, 2012, 41, 815-829.

28. B. Heurtault, P. Saulnier, B. Pech, J. E. Proust and J. P. Benoit, Biomaterials, 2003, 24, 4283-4300.

29. O. Paecharoenchai, N. Niyomtham, T. Ngawhirunpat, T. Rojanarata, B. E. Yingyongnarongkul and P. Opanasopit, J Drug Target, 2012, 20, 783-792.

30. S. Resina, P. Prevot and A. R. Thierry, PLoS One, 2009, 4, e6058.

31. A. Ferrari, V. Pellegrini, C. Arcangeli, A. Fittipaldi, M. Giacca and F. Beltram, Mol Ther, 2003, 8, 284-294.

32. D. Delgado, A. del Pozo-Rodriguez, M. A. Solinis and A. Rodriguez-Gascon, Eur J Pharm Biopharm, 2011, 79, 495-502.

33. P. Midoux and M. Monsigny, Bioconjug Chem, 1999, 10, 406-411.

34. G. P. Ochoa, J. Z. Sesma, M. A. Diez, A. Diaz-Tahoces, M. Aviles-Trigeros, S. Grijalvo, R. Eritja, E. Fernandez and J. L. Pedraz, Pharm Res, 2014. 
35. K. Remaut, N. N. Sanders, F. Fayazpour, J. Demeester and S. C. De Smedt, J Control Release, 2006, 115, 335-343.

36. A. del Pozo-Rodriguez, D. Delgado, M. A. Solinis, A. R. Gascon and J. L. Pedraz, Int J Pharm, 2008, 360, 177-183.

37. R. Leventis and J. R. Silvius, Biochim Biophys Acta, 1990, 1023, 124-132.

38. X. Gao and L. Huang, Biochem Biophys Res Commun, 1991, 179, 280-285.

39. P. Thomas and T. G. Smart, J Pharmacol Toxicol Methods, 2005, 51, 187-200.

40. R. A. Bejjani, D. BenEzra, H. Cohen, J. Rieger, C. Andrieu, J. C. Jeanny, G. Gollomb and F. F. Behar-Cohen, Mol Vis, 2005, 11, 124-132.

41. K. Corsi, F. Chellat, L. Yahia and J. C. Fernandes, Biomaterials, 2003, 24, 12551264.

42. D. Pozzi, G. Caracciolo, R. Caminiti, S. C. De Sanctis, H. Amenitsch, C. Marchini, M. Montani and A. Amici, ACS Appl Mater Interfaces, 2009, 1, 2237-2249.

43. D. Pozzi, C. Marchini, F. Cardarelli, A. Rossetta, V. Colapicchioni, A. Amici, M. Montani, S. Motta, P. Brocca, L. Cantu and G. Caracciolo, Mol Pharm, 2013, 10, 46544665.

44. D. Pozzi, C. Marchini, F. Cardarelli, F. Salomone, S. Coppola, M. Montani, M. E. Zabaleta, M. A. Digman, E. Gratton, V. Colapicchioni and G. Caracciolo, Biochim Biophys Acta, 2014, 1838, 957-967.

45. R. S. Singh and A. Chaudhuri, FEBS Lett, 2004, 556, 86-90.

46. S. Brunner, T. Sauer, S. Carotta, M. Cotten, M. Saltik and E. Wagner, Gene Ther, 2000, 7, 401-407.

47. A. J. Lin, N. L. Slack, A. Ahmad, C. X. George, C. E. Samuel and C. R. Safinya, Biophys J, 2003, 84, 3307-3316.

48. M. Jayaraman, S. M. Ansell, B. L. Mui, Y. K. Tam, J. Chen, X. Du, D. Butler, L. Eltepu, S. Matsuda, J. K. Narayanannair, K. G. Rajeev, I. M. Hafez, A. Akinc, M. A. Maier, M. A. Tracy, P. R. Cullis, T. D. Madden, M. Manoharan and M. J. Hope, Angew Chem Int Ed Engl, 2012, 51, 8529-8533.

49. J. Heyes, L. Palmer, K. Bremner and I. MacLachlan, J Control Release, 2005, 107, 276-287.

50. F. M. Goni and A. Alonso, Biosci Rep, 2000, 20, 443-463.

51. M. J. Bennett, A. M. Aberle, R. P. Balasubramaniam, J. G. Malone, R. W. Malone and M. H. Nantz, J Med Chem, 1997, 40, 4069-4078.

52. J. Smisterova, A. Wagenaar, M. C. Stuart, E. Polushkin, G. ten Brinke, R. Hulst, J. B. Engberts and D. Hoekstra, J Biol Chem, 2001, 276, 47615-47622.

53. B. E. Yingyongnarongkul, W. Radchatawedchakoon, A. Krajarng, R. Watanapokasin and A. Suksamrarn, Bioorg Med Chem, 2009, 17, 176-188.

54. A. M. Aberle, F. Tablin, J. Zhu, N. J. Walker, D. C. Gruenert and M. H. Nantz, Biochemistry, 1998, 37, 6533-6540.

\section{FIGURES}




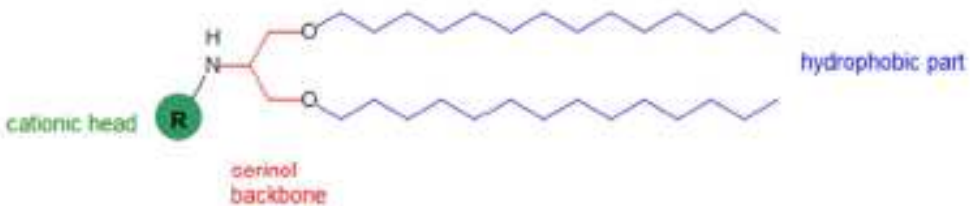

backbone

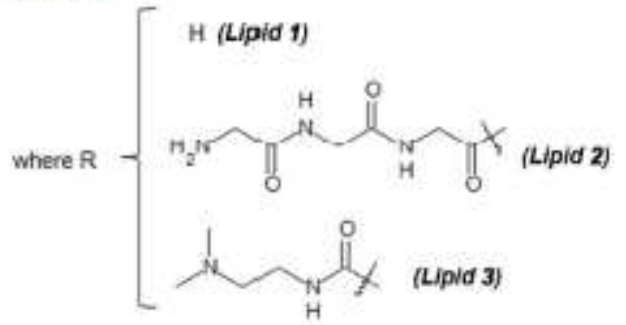

Fiaure 1. General structure for the novel amino lipid-based serinol derivatives (lipids 1, 2 and 3) containina

the same backbone, hydrophobic part and several cationic heads

$211 \times 123 \mathrm{~mm}(96 \times 96 \mathrm{DPI})$

Figure 1. General structure for the novel amino lipid-based serinol derivatives (lipids 1, 2 and 3) containing the same backbone, hydrophobic part and several cationic heads. 


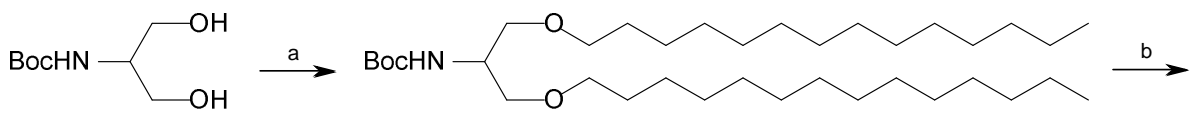

5

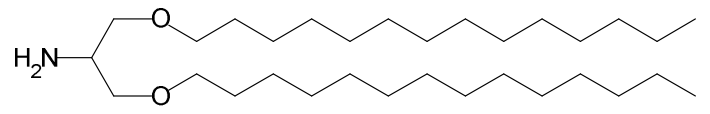

1

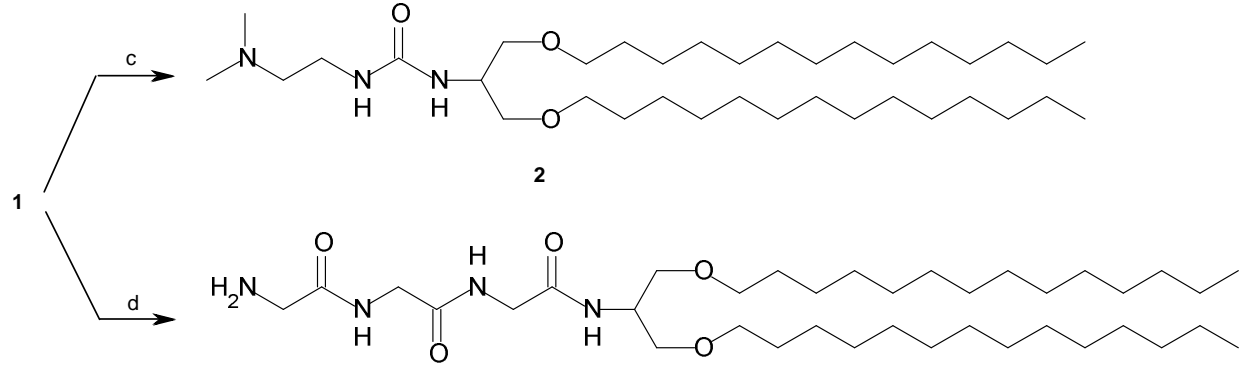

Reagents and Conditions a. Alkyl bromide $\left(\mathrm{C}_{14} \mathrm{H}_{29} \mathrm{Br}\right), \mathrm{Bu}_{4} \mathrm{NHSO}_{4}, \mathrm{NaOH} 50 \%$, Toluene, $60{ }^{\circ} \mathrm{C}$, overnight; b. i. DCM:TFA $10 \%$, r.t., $30 \mathrm{~min}$; ii. carbonate resin, AcOEt, r.t., $1 \mathrm{~h}$; c. i. $p$-nitrophenyl-chloroformate, DIEA, THF:DCM, r.t., 4h; ii. 2-dimethylaminethyleneamine, DMF, r.t., overnight; d. i. 3GlyBoc-OH, NHS, EDC, DCM, r.t., overnight; ii. DCM:TFA 10\%, 30 min, r.t., iii. 6, carbonate resin, AcOEt:MeOH (1:5), r.t., $1 \mathrm{~h}$

Figure 2. Synthetic strategy for the synthesis of the ionizable lipids $\mathbf{1}, 2$ and $\mathbf{3}$. 

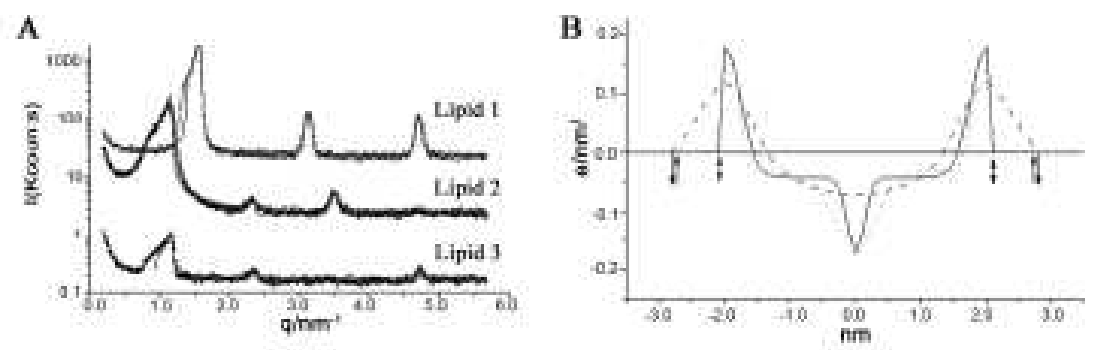

Figure 3. A) Scattered intensity at $25{ }^{\circ} \mathrm{C}$ of the lipids after incubation with HEPES buffer. The lines correspond to the best fit of correlated lamellae, see text for the details. The curves have been scaled by factors of 10, the original scale corresponds to lipid 3. B). Electron density contrast relative to water perpendicular to the bilayer for lipid 1 (full line, upper-down arrow), Lipid 2 (dashed line, down arrow) and lipid 3 (dotted line, up arrow) as obtained from the fits of the scattering curves of figure A. The arrows mark the limit of the corresponding layer.
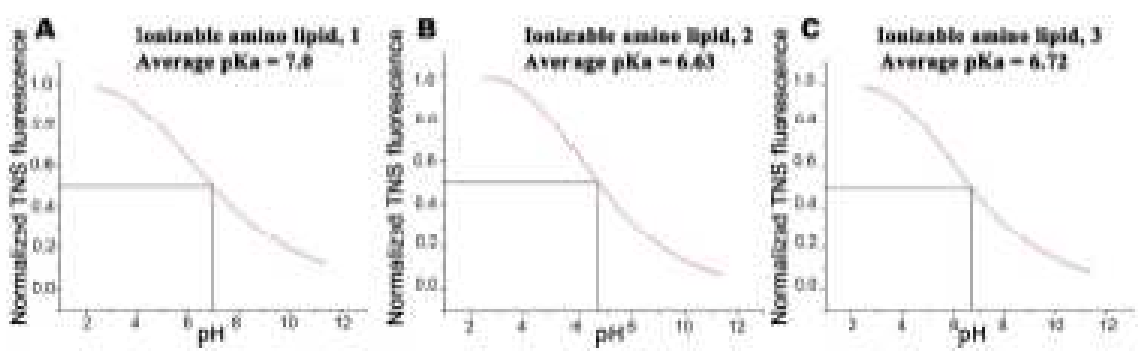

Figure 4. In situ TNS fluorescence titration to determining the pka of niosomes bases on three cationic lipids. A) Sigmoidal curve showing TNS fluorescence as a function of $\mathrm{pH}$ in the presence of lipid $\mathbf{1}$ (75 $\mu \mathrm{M})$, TNS $(1 \mu \mathrm{M})$ and buffer solution (total volume $100 \mu \mathrm{L}$ ), B) Sigmoidal curve showing TNS fluorescence as a function of $\mathrm{pH}$ in the presence of lipid $2(75 \mu \mathrm{M})$, TNS $(1 \mu \mathrm{M})$ and buffer solution (total volume $100 \mu \mathrm{L}$ ), C) Sigmoidal curve showing TNS fluorescence as a function of $\mathrm{pH}$ in the presence of lipid $3(75 \mu \mathrm{M})$, TNS $(1 \mu \mathrm{M})$ and buffer solution (total volume $100 \mu \mathrm{L})$. 

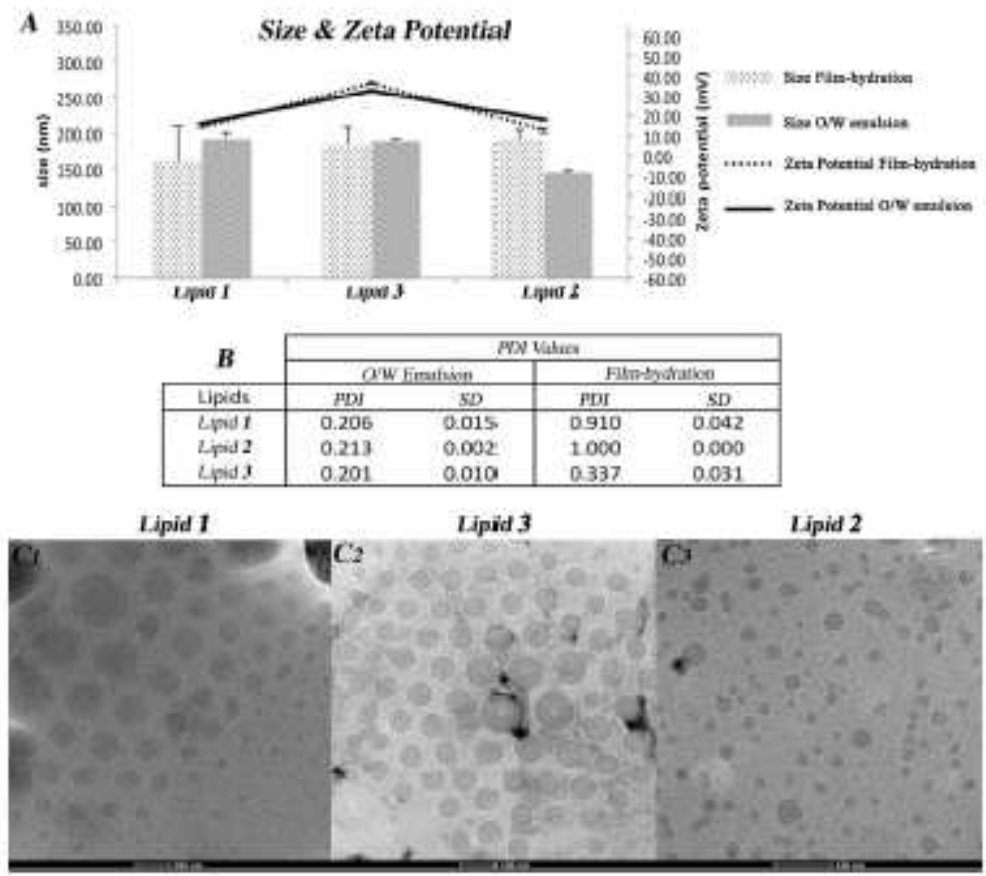

Figure. 5. Physicochemical characterization of niosomes based on lipids 1, 3 and 2. A) Size (dotted and hatched bars, which correspond to niosomes synthesized by film-hydration and o/w emulsion techniques respectively) and Zeta potential values (dotted and continuous lines which correspond to niosomes synthesized by film-hydration and o/w emulsion techniques respectively). B) PDI values. Each value represents the mean \pm standard deviation of three measurements. C) Cryo-TEM images of niosomes prepared by the o/w emulsion technique. Niosomes were based on lipid 1 (C1), lipid 3 (C2) and lipid 2 (C3). Scale bar $=100 \mathrm{~nm}$. 

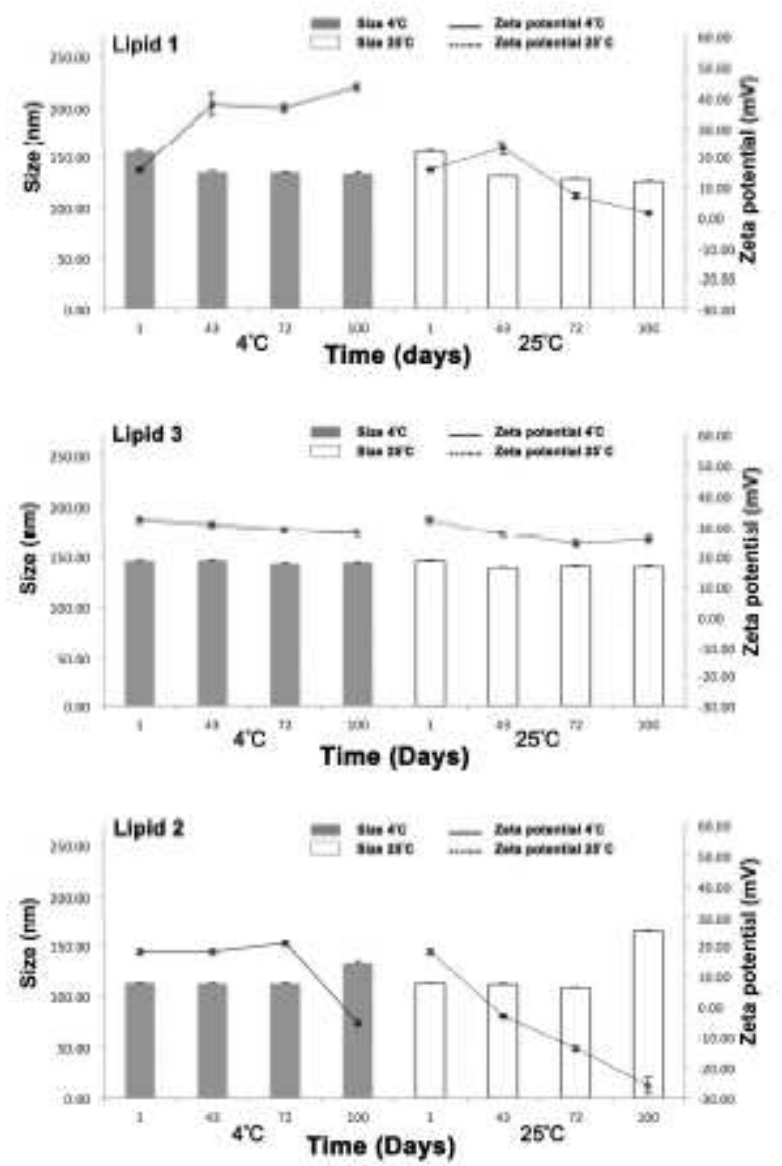

Figure 6. Physical stability of niosomes based on lipid 1 (A), lipid 3 (B) and lipid 2 (C), following storage at $4^{\circ} \mathrm{C}$ and $25^{\circ} \mathrm{C}$ for 100 days. Dark and white bars correspond to particle sizes obtained at $4^{\circ} \mathrm{C}$ and $25^{\circ} \mathrm{C}$ respectively, while continuous and dotted lines correspond to zeta values obtained at $4^{\circ} \mathrm{C}$ and $25^{\circ} \mathrm{C}$. A) lipid 1, B) lipid 3 and C) lipid 2. Each value represents the mean \pm standard deviation (SD) from three independent experiments. 

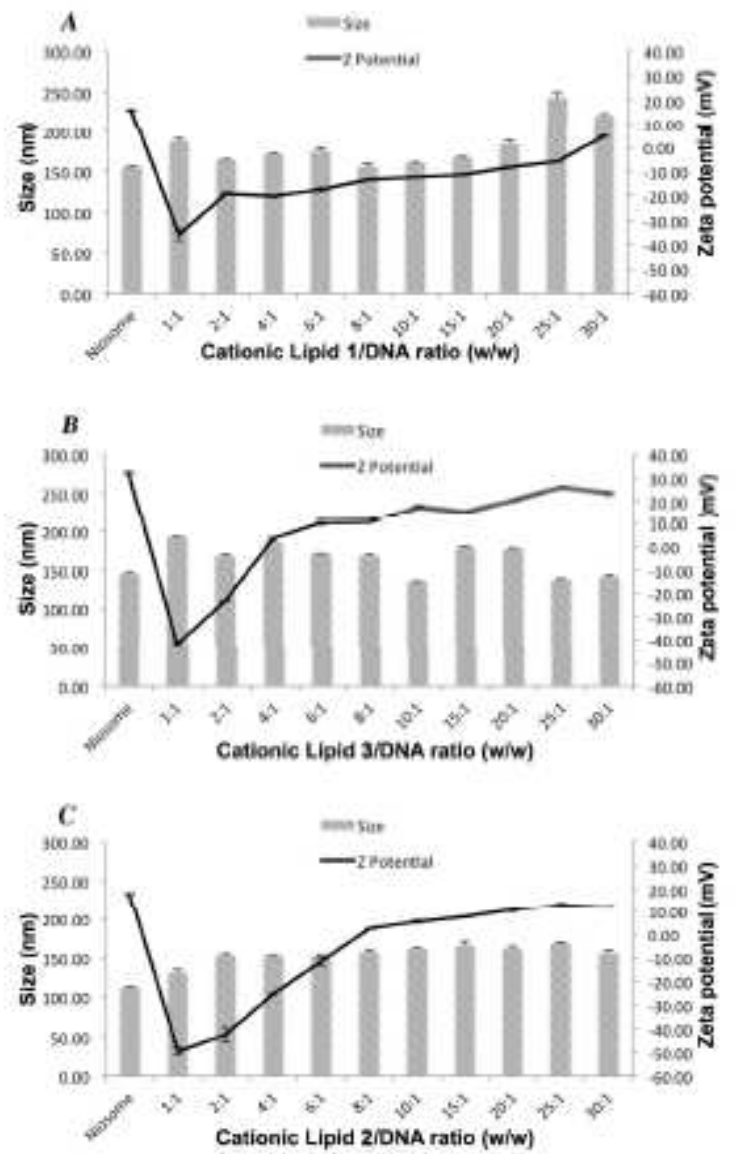

Figure. 7. The influence of the cationic lipid/DNA ratio (w/w) on the particle size (bars) and zeta potential (lines) of niosomes based on: A) lipid 1, B) lipid 3 and C) lipid 2. Each value represents the mean \pm standard deviation of three measurements. 


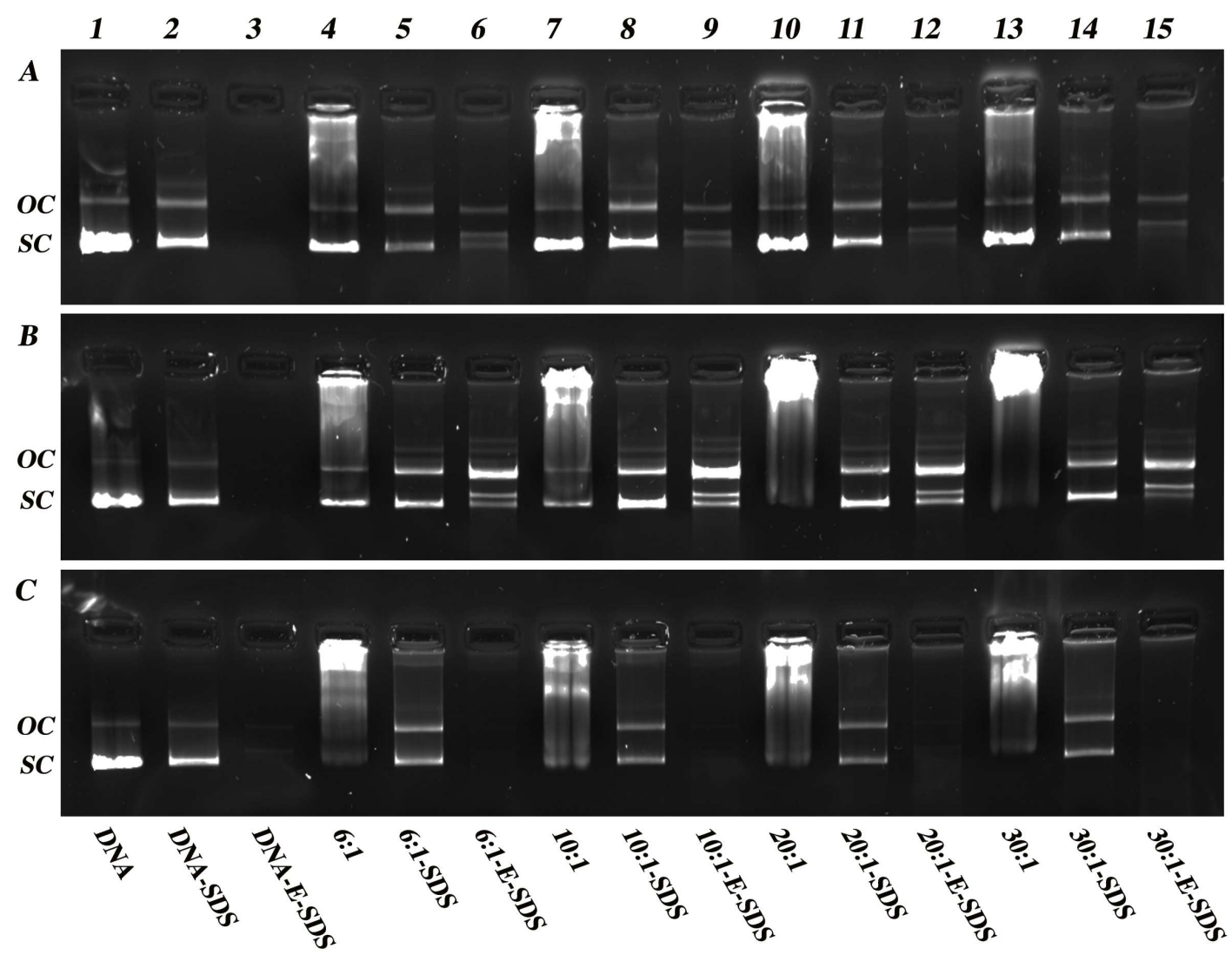

Figure 8. Binding, protection, and SDS-induced release of DNA from niosomes at different cationic lipid/DNA ratios (w/w) visualized by agarose electrophoresis. OC: open circular form, SC: supercoiled form. Lanes 1-3 correspond to free DNA; lanes 4-6, cationic lipid/DNA ratio 6/1; lanes 7-9, cationic lipid/DNA ratio 10/1; lanes 10-12, cationic lipid/DNA ratio 20/1; lanes 13-15, cationic lipid/DNA ratio 30/1. Nioplexes were treated with SDS (lanes 2,5,8,11 and 14) and DNase I + SDS (lanes 3,6,9,12 and 15). A) Nioplexes based on cationic lipid 1, B) Nioplexes based on cationic lipid 3, C) Nioplexes based on cationic lipid 2 . 

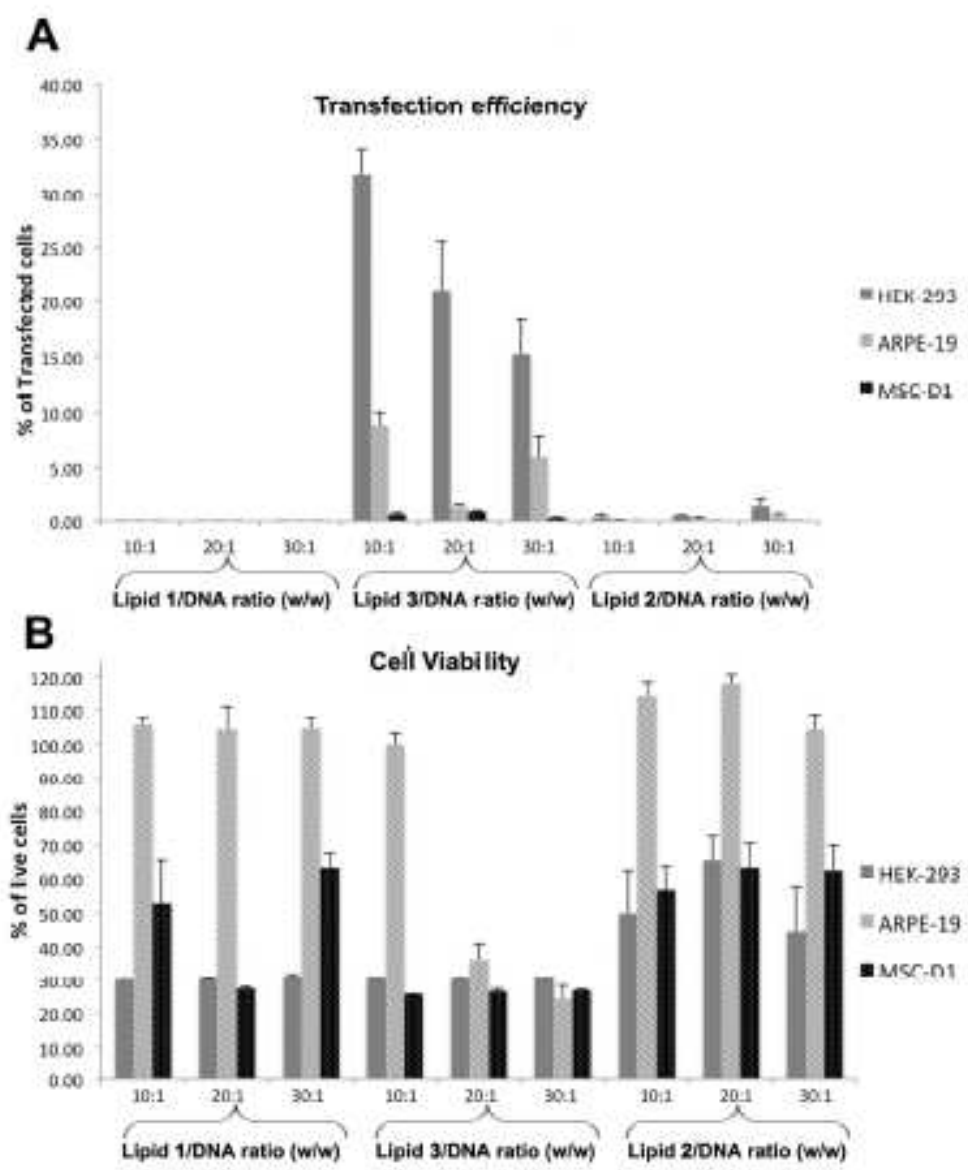

Figure 9. In vitro transfection experiments of nioplexes based on cationic lipids 1, 3 and $\mathbf{2}$ in HEK-293, ARPE-19 and MSC-D1 cells. A) Transfection efficiency at different cationic lipid/DNA ratios (w/w). B) Cell viability at different cationic lipid/DNA ratio (w/w). 
SUPPLEMENTARY MATERIAL.

In situ TNS fluorescence tritation to determining pka of cationic lipids (1, 2 and 3) Sigmoidal curve showing TNS fluorescence as a function of $\mathrm{pH}$ in the presence of amino linid $1(75 \mathrm{uM})$. TNS (1 uM) and huffer solution (total volume $100 \mu \mathrm{L}$ )

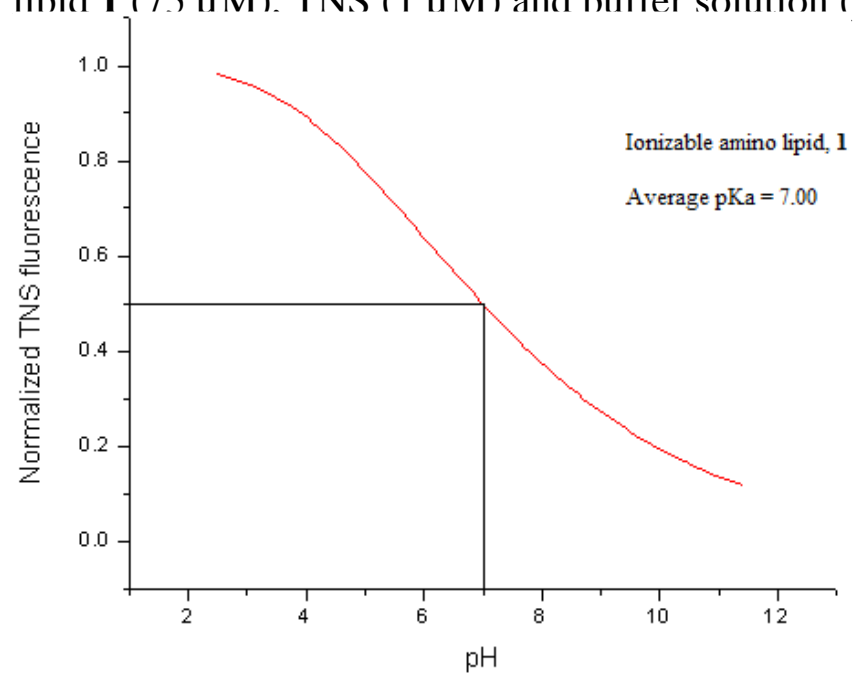

Sigmoidal curve showing TNS fluorescence as a function of $\mathrm{pH}$ in the presence of amino linid 2 (75 uM). TNS ( 1 uM) and buffer solution (total volume $100 \mu \mathrm{L}$ )

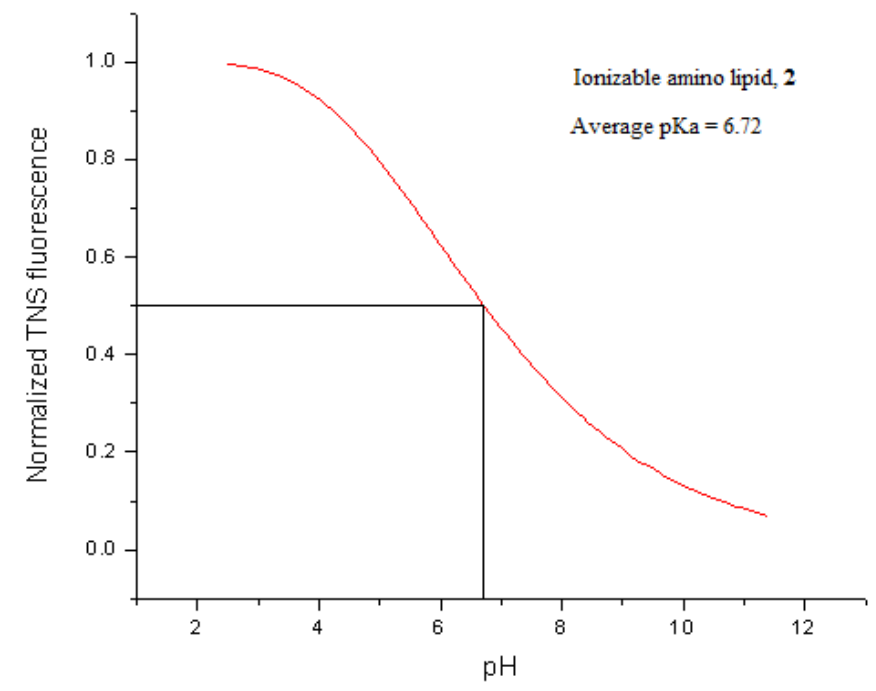


Sigmoidal curve showing TNS fluorescence as a function of $\mathrm{pH}$ in the presence of amino linid $3(75 \mathrm{uM})$. TNS (1 u M) and buffer solution (total volume $100 \mu \mathrm{L}$ )

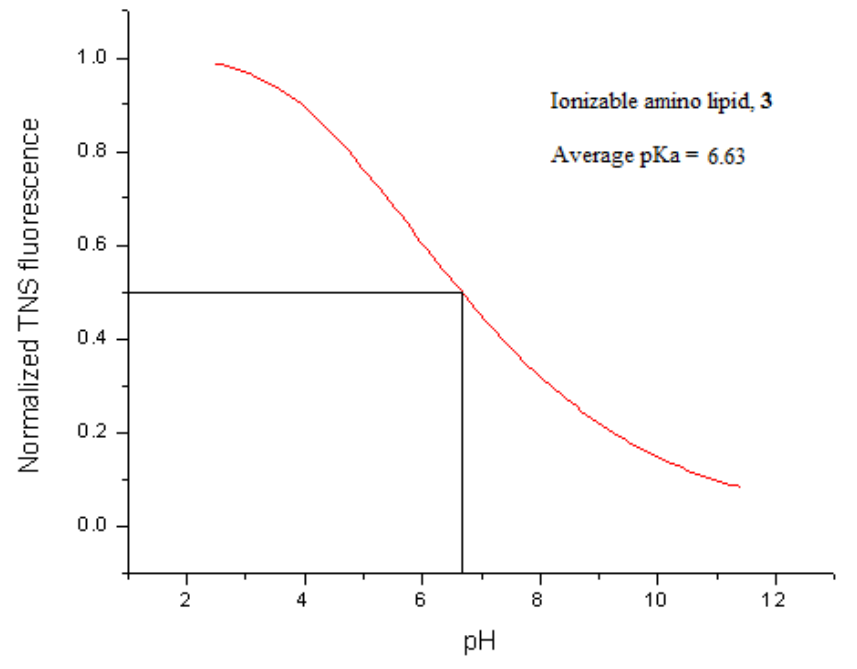


tert-butyl- $N$-[2-tetradecoxy-1-(tetradecoxymethyl)ethyl]carbamate (2)<smiles>CCCCCCCCCCCCCCOCC(COCCCCCCCCCCCCCC)NC(=O)O</smiles>
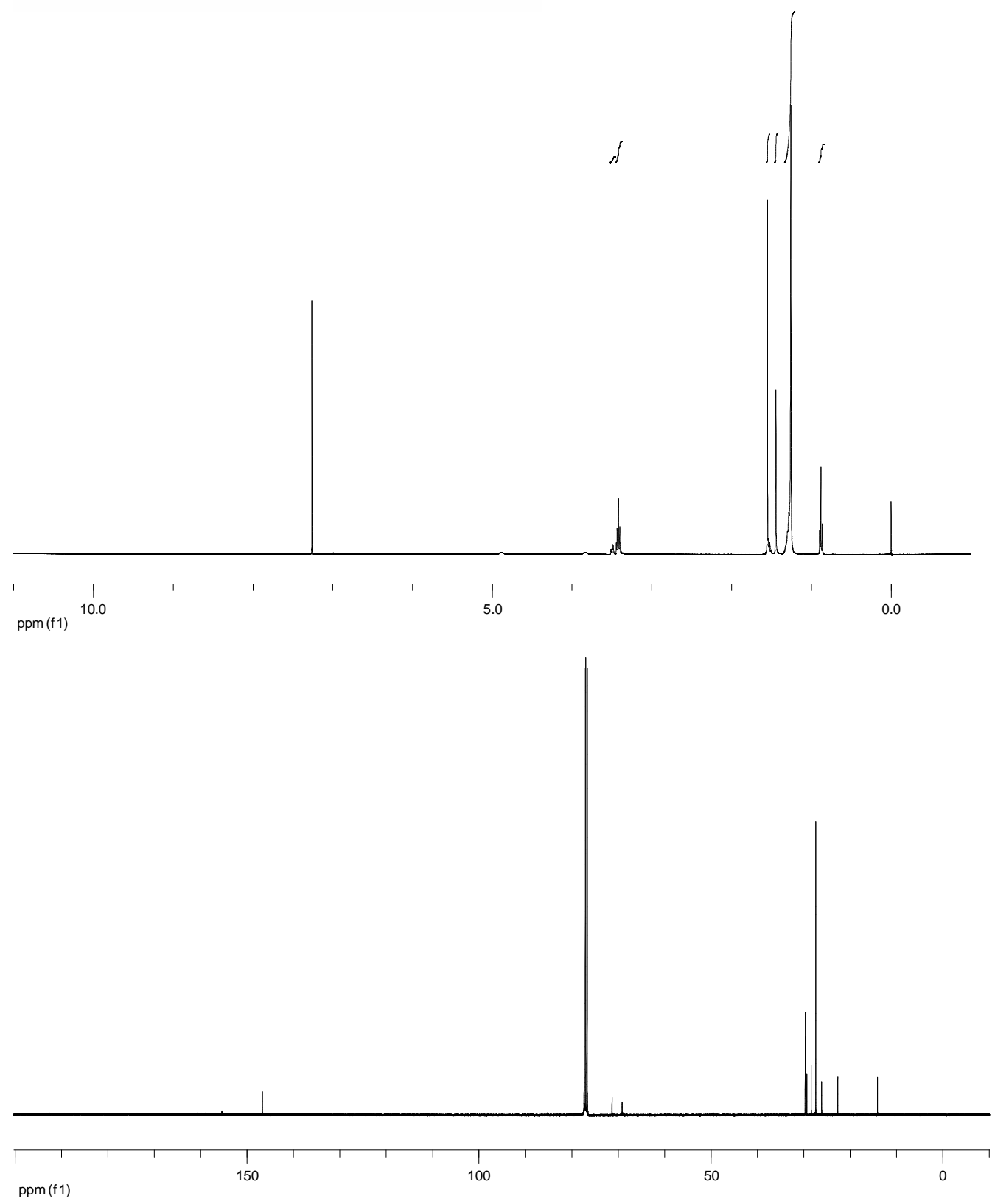


\section{1,3-di(tetradecoxy)propan-2-amine (3)}
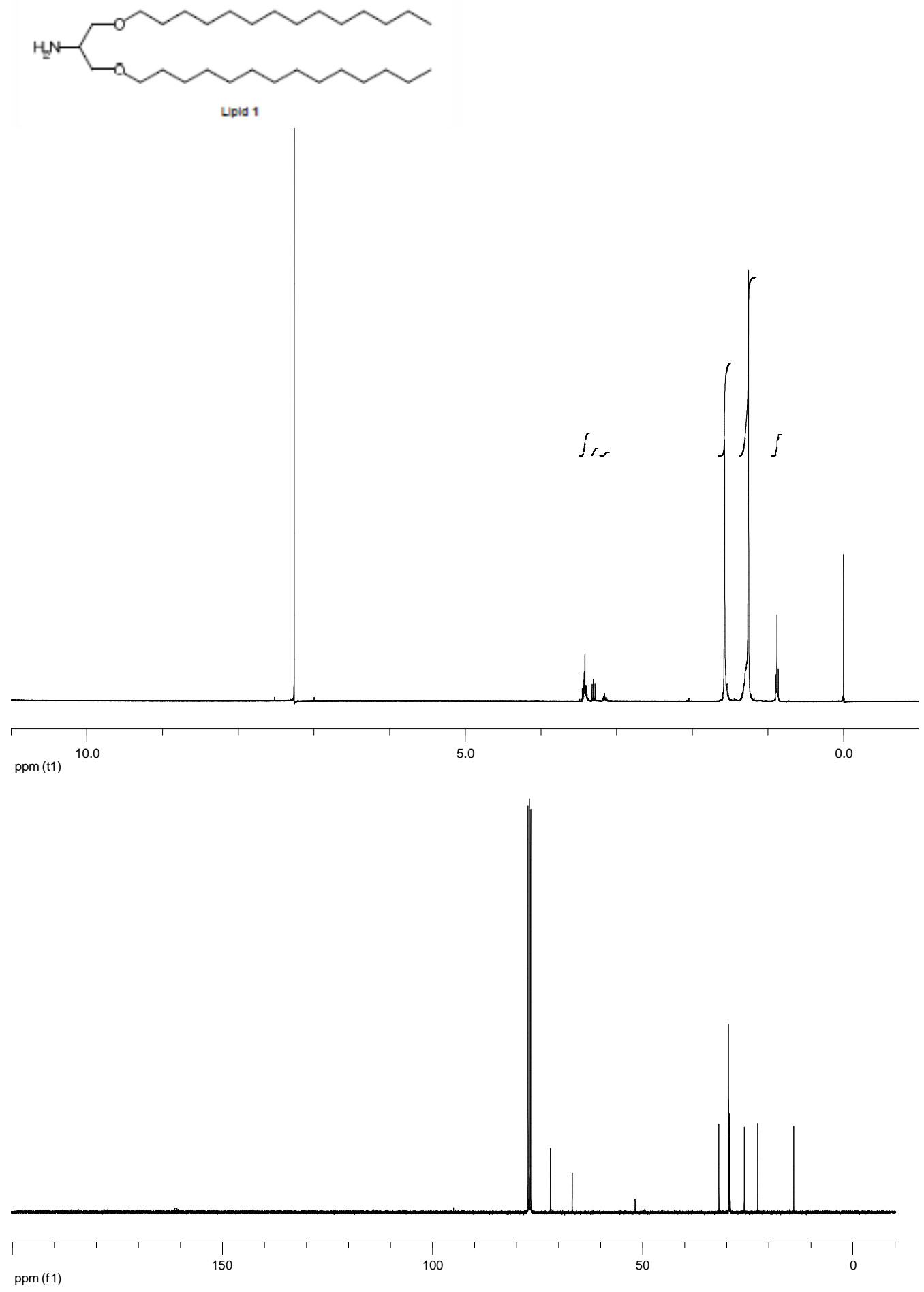
1-(2-dimethylaminoethyl)-3-[2-tetradecoxy-1-(tetradecoxymethyl)ethyl]urea (4)
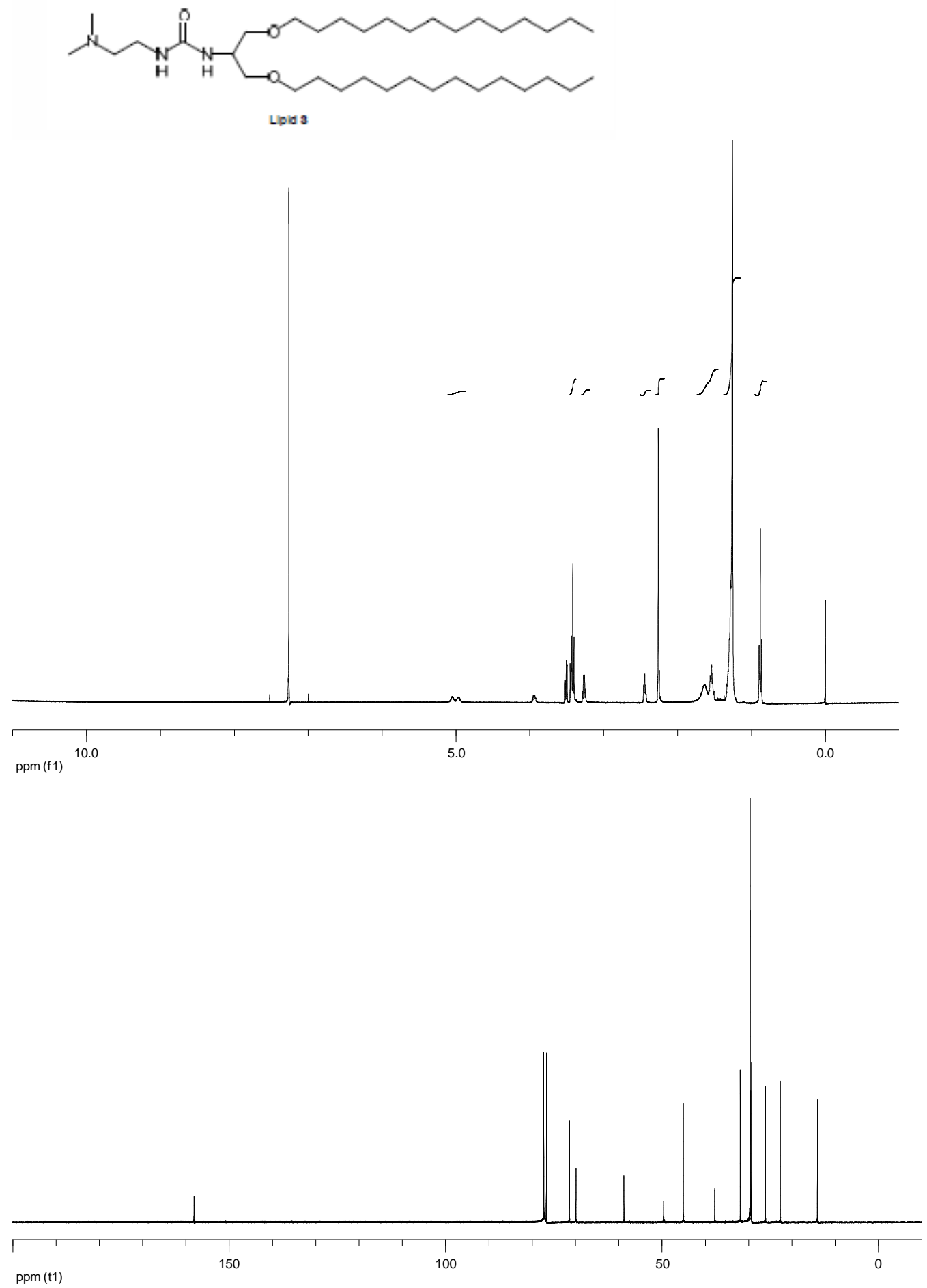
tert-butyl- $N$-[2-oxo-2-[[2-oxo-2-[[2-oxo-2-[[2-tetradecoxy-1-(tetradecoxymethyl)ethyl]amino]ethyl]amino] ethyl]amino]ethyl]carbamate (5)

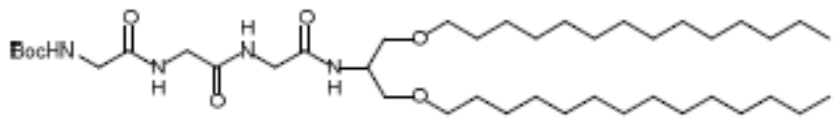
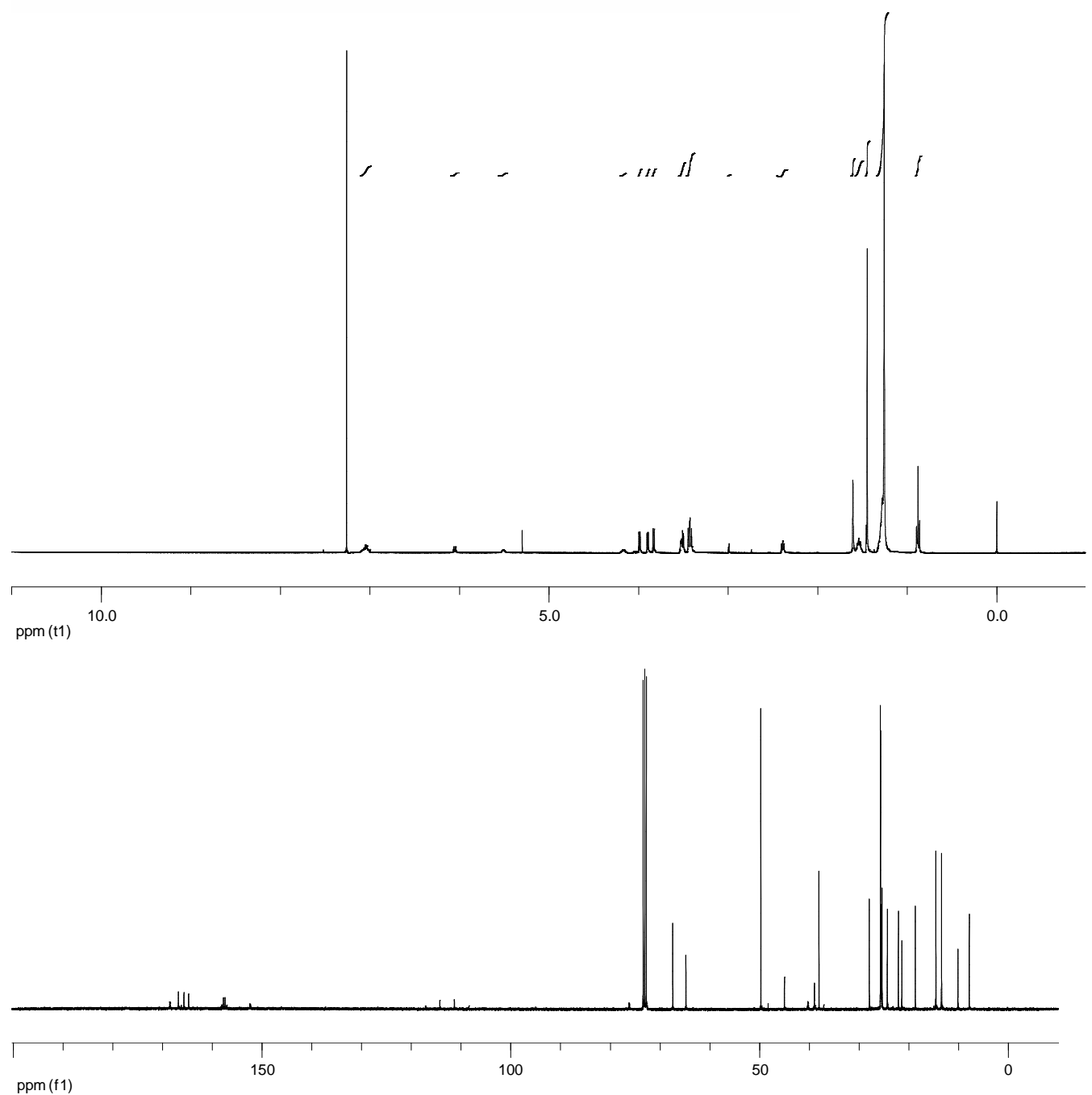
2-[[2-[(2-aminoacetyl)amino]acetyl]amino]-N-[2-tetradecoxy-1(tetradecoxymethyl)ethyl]-acetamide (6)

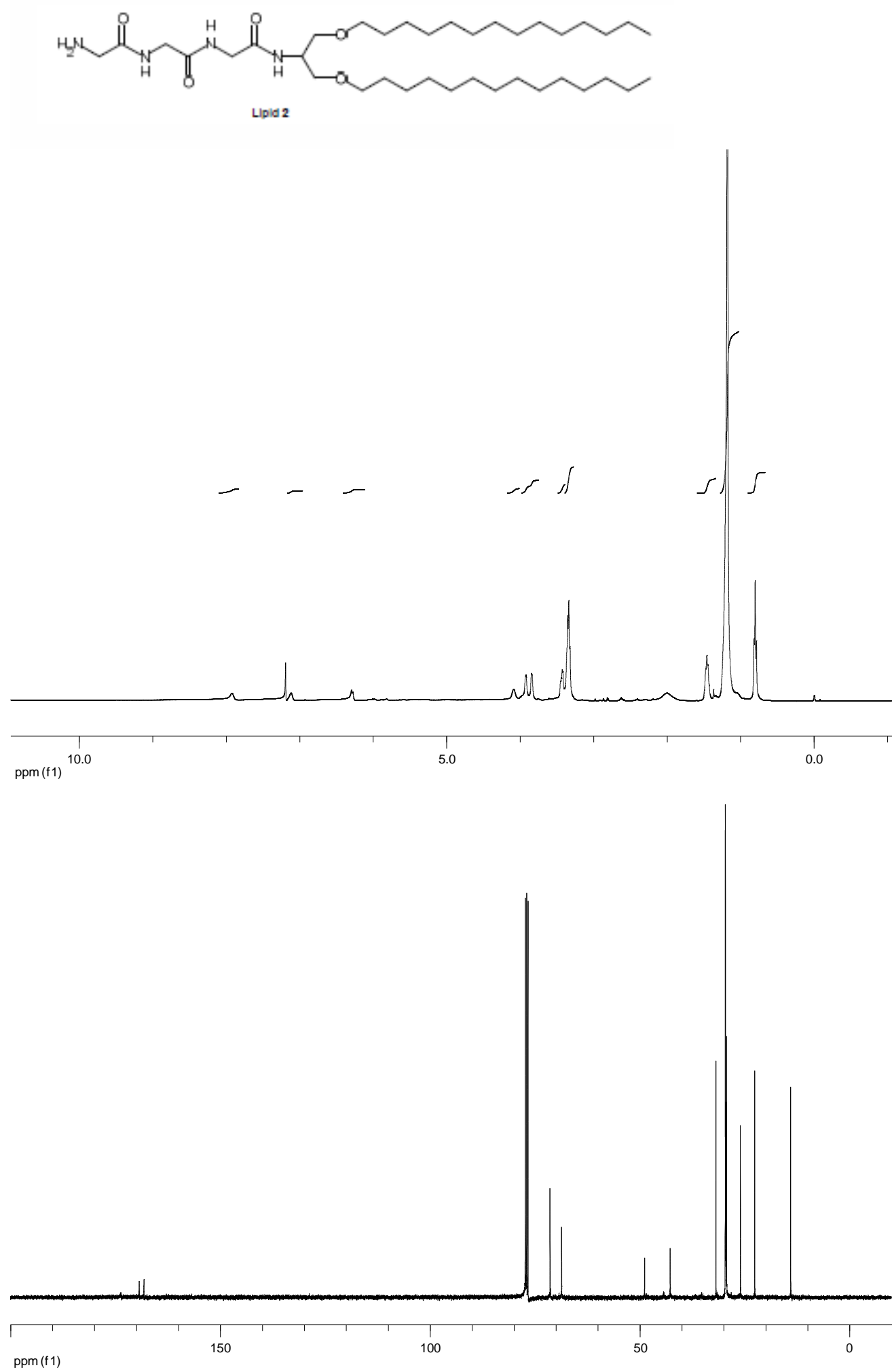


Table S1. Main parameters of the fits corresponding to the Figure 3B

\begin{tabular}{|l|l|l|l|}
\hline & Lipid 1 & Lipid 2 & Lipid 3 \\
\hline reduced $\chi^{2}$ & 50 & 65 & 6 \\
\hline$d(\mathrm{~nm})$ & 4.08 & 5.47 & 5.41 \\
\hline$\eta$ & 0.0176 & 0.03758 & 0.00882 \\
\hline$N$ & 68 & 100 & 111 \\
\hline$\sigma_{H}(\mathrm{~nm})$ & 0.22 & 0.37 & 0.12 \\
\hline$\rho_{H}\left(\mathrm{e} / \mathrm{nm}^{3}\right)$ & 182 & 126 & 178 \\
\hline$Z_{H}(\mathrm{~nm})$ & 1.98 & 1.98 & 1.91 \\
\hline$\sigma_{H}(\mathrm{~nm})$ & 0.13 & 1.02 & 0.31 \\
\hline $\mathrm{Z}_{C H 2}(\mathrm{~nm})$ & 1.75 & 1.60 & 1.89 \\
\hline$A_{m}\left(\mathrm{~nm}^{2}\right)$ & 0.46 & 0.45 & 0.46 \\
\hline$N_{w}$ & 1 & 6 & 1 \\
\hline$N_{w}{ }^{*}$ & 0 & 0 & 5 \\
\hline
\end{tabular}

$d$ repetition distance, $\eta$ Caillé parameter, $N$ number of correlated bilayers, $\sigma_{H}$ width of the polar head Gaussian, $\rho_{H}$ electron density relative to the water medium, $Z_{H}$ position of the polar head Gaussian, $\sigma_{H}$ width of the methyl Gaussian, $Z_{C H 2}$ width of the methylene error function, $A_{m}$ area per lipid molecule, $N_{w}$ bound water molecules, $N_{w}{ }^{*}$ free water molecules. 